\title{
Soil-Transmitted Helminth Vaccines: Are We Getting Closer?
}

\author{
Ayat Zawawi ${ }^{1 *}$ and Kathryn J. Else ${ }^{2 *}$ \\ ${ }^{1}$ Department of Medical Laboratory Technology, Faculty of Applied Medical Sciences, King Abdulaziz University, Jeddah, \\ Saudi Arabia, ${ }^{2}$ Manchester Academic Health Science Centre, Faculty of Biology, Medicine, and Health, School of Biological \\ Sciences, Lydia Becker Institute of Immunology and Inflammation, University of Manchester, Manchester, United Kingdom
}

\section{OPEN ACCESS}

Edited by:

Mark C. Siracusa,

Rutgers Biomedical and Health

Sciences, United States

Reviewed by:

Keke Celeste Fairfax,

The University of Utah, United States William Horsnell,

University of Cape Town, South Africa

*Correspondence: Ayat Zawawi

atzawawi@kau.edu.sa

Kathryn J. Else

kathryn.j.else@manchester.ac.uk

Specialty section:

This article was submitted to

Microbial Immunology,

a section of the journal

Frontiers in Immunology

Received: 26 June 2020 Accepted: 02 September 2020

Published: 30 September 2020

Citation:

Zawawi A and Else KJ (2020) Soil-Transmitted Helminth Vaccines:

Are We Getting Closer?

Front. Immunol. 11:576748. doi: 10.3389/fimmu.2020.576748
Parasitic helminths infect over one-fourth of the human population resulting in significant morbidity, and in some cases, death in endemic countries. Despite mass drug administration (MDA) to school-aged children and other control measures, helminth infections are spreading into new areas. Thus, there is a strong rationale for developing anthelminthic vaccines as cost-effective, long-term immunological control strategies, which, unlike MDA, are not haunted by the threat of emerging drug-resistant helminths nor limited by reinfection risk. Advances in vaccinology, immunology, and immunomics include the development of new tools that improve the safety, immunogenicity, and efficacy of vaccines; and some of these tools have been used in the development of helminth vaccines. The development of anthelminthic vaccines is fraught with difficulty. Multiple lifecycle stages exist each presenting stage-specific antigens. Further, helminth parasites are notorious for their ability to dampen down and regulate host immunity. One of the first significant challenges in developing any vaccine is identifying suitable candidate protective antigens. This review explores our current knowledge in lead antigen identification and reports on recent pre-clinical and clinical trials in the context of the soil-transmitted helminths Trichuris, the hookworms and Ascaris. Ultimately, a multivalent anthelminthic vaccine could become an essential tool for achieving the medium-to long-term goal of controlling, or even eliminating helminth infections.

Keywords: helminth, hookworm, Trichuris, Ascaris, vaccine, vaccine-induced immunity

\section{INTRODUCTION}

Neglected tropical diseases (NTDs) remain a global public health issue. Their impact is especially felt in areas with poor hygiene and sanitation, and are related to extreme poverty and lack of health education (1). Some of the most "neglected" diseases are caused by soil-transmitted helminths (STHs), which together infect more than a quarter of the world's population (2). The four most prevalent STHs worldwide are the Hookworms Necator americanus and Ancylostoma duodenale, the roundworm Ascaris lumbricoides, Strongyloides stercoralis, together with the whipworm Trichuris trichiura (3). The highest intensity of infection for A. lumbricoides and T. trichiura is typically seen in school-aged children and adolescents, whilst in hookworm infections infection intensity tends to increase with age, plateauing in to adulthood. Those who travel to and from regions where STH infections are endemic are also at risk of getting infected $(4,5)$. Although little is known about S. stercoralis in comparison to Ascaris, Trichuris and hookworm despite prevalence estimates of up to $40 \%$ in tropical countries (6-9) there is a growing understanding of the immune response to infection $(10,11)$. However, a biochemical understanding of the parasite remains 
limited and thus, this review will focus on vaccines against the human hookworms (12), whipworm and roundworm (13).

The ability to control STH infections currently depends almost exclusively on mass anti-helminthic drug administrations (MDA) such as albendazole or mebendazole to at-risk populations $(4,5,14,15)$ in conjunction with education and improved sanitation including WASH initiatives $(16,17)$. However, post-treatment reinfection is common, especially for helminth species such as Ascaris and Trichuris, where the robust parasite eggs are nearly ubiquitous in the environment. Such extensive contamination of soil with parasite eggs limits the ability of MDA programs, global control and elimination efforts to interrupt the transmission cycle within a community (18). Moreover, the appearance of anthelmintic-resistant parasites threatening human drug treatment programmes $(19,20)$ has increased interest in developing vaccines, or a pan-anthelminthic vaccine to provide a cost-effective, long-term immunological method to control multiple helminth infections (21-23).

This review explores our current knowledge, prospects, and challenges for anti-human STHs vaccine design. Although of significant importance, the review does not cover veterinary vaccines which have been reviewed recently (24). We include the importance of understanding the underpinning immune responses required to eliminate STHs from their host, opportunities for antigen-presenting cell targeting of candidate antigens, and include recent pre-clinical and clinical trials in the context of Ascaris, Trichuris and the hookworms.

\section{PROSPECTS AND CHALLENGES FOR ANTI-STHS VACCINE DESIGN}

The development of efficient anti-STH vaccines is thought to represent a greater challenge compared to developing antibacterial or anti-viral vaccines. This is partly a result of the complex lifecycles of STHs, combined with an incomplete immunological knowledge of the host-parasite interactions and the immune mechanisms conferring protection (25). Moreover, STHs have complex genomes and proteomes (26-30). This complexity makes it difficult to identify antigenic targets for the development of an effective vaccine (31). Despite these obstacles, the development of vaccines against the STHs has progressed over the decades.

\section{Identifying Lead Antigens to Include in Vaccines \\ Crude Antigen Preparations}

The earliest anthelmintic vaccines included attenuated or irradiation-killed parasites $(32,33)$. Since this time, extensive studies across many helminth spp have explored the immunogenicity of native molecules excreted and/or secreted by parasites (the so-called ES molecules) (34-37) and parasite-derived extracellular vesicles (EVs) in promoting resistance to infection (38-41). Excreted and secreted parasite molecules make excellent vaccine candidates as they sit at the host-parasite interface, playing critical roles in both the modulation of host immunity and in inducing Th2-skewed immune responses $(35,42)$.

\section{Recombinant Proteins}

Instead of targeting the immune response against a mixture of antigens, a particular antigen from the pathogen can be produced and expressed in a heterologous expression system to focus the immune response toward a specific antigen of the pathogen to prevent the infection $(43,44)$. Such an approach ensures that safer and more reliable vaccines are developed, with an example being the licensed recombinant hepatitis B vaccine (45). The key therefore to an effective recombinant vaccine is to identify that particular conserved antigen or combination of antigens secreted or extracted from the pathogen that can overcome the low protective immunity naturally generated by the infection $(44,46)$. However, recombinant vaccines often require an adjuvant and multiple immunizations to elicit a protective and long-lasting immune response (47). Moreover, the production of recombinant proteins using bacterial heterologous expressions can prove challenging. Thus, antigens in which proteolytic stability, higher production yield and post-translational modifications (e.g., phosphorylation and glycosylation) are needed, other expression systems such as yeast, insect, plant, or mammalian cells should be considered (44). Of the most successful helminth recombinant vaccines are the two against hookworm disease caused by Necator americanus, which consist of aspartic protease-1 (Na-APR-1) and glutathione-S-transferase-1 (Na-GST-1). These vaccines are currently in phase 1 of clinical trials (48-50).

\section{DNA Based Vaccines}

The availability of genome sequences opened up the prospect of the DNA vaccine approach to validate novel vaccine candidates individually or combined to improve vaccine elicitation of cellmediated and mucosal immunity $(51,52)$. DNA vaccines are simple rings of DNA containing a gene encoding a specific vaccine antigen under the regulation of a promotor (53). DNA vaccine technology has been intensively used to develop vaccines against various pathogens $(54,55)$, cancer $(56)$, and autoimmune disorders (57). For example, the human immunodeficiency virus1 (both as a prophylactic and an immunotherapeutic vaccine) (58, 59), Zika virus (60), and Ebola virus vaccines (61) are currently in clinical trials. Comparatively, little progress has been made toward developing DNA vaccines against parasitic diseases, although several pre-clinical studies have shown promising results against hookworm infections $(62,63)$, malaria $(64,65)$, leishmaniasis $(66,67)$, and schistosomiasis $(68,69)$. Even though DNA vaccines offer several advantages when compared with recombinant vaccines, such as safety, improper protein folding and production cost, they have not been shown to be sufficient to induce a protective immune response (70). Therefore, DNA encapsulation, plasmid alterations, co-expressing cytokines and heterologous prime-boost approaches have been explored to enhance the immune responses induced by the DNA vaccine $(71,72)$. 


\section{Epitope-Based Vaccines}

The advent of the genome era and the tremendous advances in immunological and bioinformatics tools have enabled the reverse vaccinology approach (RV) as a new effective strategy for lead antigen identification in vaccine development (73-75). One of the advantages of the RV approach is that every antigen encoded in the worm genome can be screened in silico to determine its ability to induce an immune response $(31,74)$. Thus, it can overcome some of the limitations of conventional methods of screening vaccine candidates (76-78). Antigen selection can also be carefully prescribed based on clear inclusion and exclusion criteria. For example, Zawawi et al. employed a systematic, multi-stage process to identify Trichuris epitope vaccine antigens based on the RV approach (79). The epitopes were identified from secreted, and surface-exposed proteins and any protein with any degree of homology to humans or mice were excluded to eliminate potential autoimmune reactions. Most of the identified vaccine antigens were stage-specific and had essential functions in the parasite biological process, associated with host-parasite interaction, parasite metabolism, development and fecundity (80).

\section{The Search for a Pan-Anthelmintic Vaccine}

Coinfections with two or multiple STHs are extremely common in sub-Saharan Africa and elsewhere in the developing countries (1, 81). The three STHs hookworm, Ascaris and Trichuris also share highly conserved antigens that are likely to have very similar biological functions (46). Thus, researchers have proposed a single pan-anthelmintic vaccine against the three major human STHs to generate strong, lasting immunity with minimal side effects (23). RV methodologies have much to offer in this context. Thus, with the availability of parasite genomes and bioinformatics tools to select out IgE-inducing epitopes in silico, the development of a pan-anthelmintic vaccine based on protective epitopes from cross-protective antigens may represent an exciting alternative to the use of whole antigens.

The choice of lead antigen also determines the biomechanical requirements of production, and the design of the laboratory and clinical trials (82-84). For example, vaccines based on native antigens, are known to generate significant immunity against many STHs in pre-clinical models (85-87). However, they have many manufactory limitations, such as high cost, time consumption, difficulty of purifying large quantities of worm antigens, low stability, shelf-life, shortage of in vitro methods for the culture of parasites and control over differences in batches to develop a commercially stable vaccine (88-90). Approaches such as recombinant (91), DNA (92), and epitope-based vaccines (93) overcome some of the limitations associated with native antigens. However, most vaccines against STHs remain in earlystage development or are undergoing pre-clinical evaluation.

\section{Adjuvants: Key Components in Modern Vaccinology}

The effectiveness of lead antigens is often restrained by an inherent lack of immunostimulation. Therefore, efforts have focused on co-administering antigens with vaccine adjuvants as a key component in modern vaccinology, aiming to intensify the immune response and generate effective immunological memory (94). In addition, adjuvants are important in overcoming immune senescence seen in the elderly (95), and expanding the antibody repertoire generated (96). Adjuvants may also allow dose-sparing (97) and careful choice of adjuvants used provides the ability to guide the type of immune response generated $(98,99)$. The specific type of $\mathrm{T}$ helper response generated plays critical role in the efficacy of the protective immune response, as a Th1-type response is critical in developing vaccines against intracellular pathogens, whereas Th2-type responses are critical in developing vaccines against extracellular parasites (100).

Among the earliest adjuvants used in experimental antibody production were Freund's adjuvants $(101,102)$. However, as these adjuvants are associated with pain, inflammation, and tissue destruction they are no longer used and have been replaced by other adjuvants that can produce equal or superior antibody responses with less inflammation and tissue destructions (103).

The two adjuvants that are licensed for use in humans, aluminum salt and squalene oil-based emulsion (MF59), mainly promote Th2-biased immune responses $(99,104)$. Each adjuvant has its own immunological signature. For example, alum increased antibody titers, whereas MF59 induces strong antibody and IL-5 responses in mice (105). However, their mechanisms of action remain only partially understood.

Nanoparticulate vaccine adjuvants and delivery vehicles have also been incorporated into vaccine design to enhance the humoral and cellular immune responses $(106,107)$. Vaccine delivery systems include synthetic nano- and micro-particles, immunostimulatory complexes, liposomes, virosome, and viruslike particles (VLP) (108). These approaches promote the uptake of antigens by different antigen-presenting cells, promote their migration and maturation from the site of vaccine uptake and protect antigens from degradation $(106,109,110)$. VLPs, for example, possess the immunostimulatory and self-adjuvanting properties of natural viruses but do not contain genetic material $(111,112)$. In addition, they are very stable and can withstand adverse environments, such as those with acidic $\mathrm{pH}$, making VLPs an attractive carrier for mucosally administered vaccines (113). RTS, S (Mosquirix) was the first licensed VLP-based vaccine generated against parasitic disease (114). It is composed of three tandem repeat (R) and cell (T) epitopes from the circumsporozoite protein of the $P$. falciparum malaria parasite, which are displayed on hepatitis B surface particles (HBs-Ag) (S), co-expressed in Saccharomyces cerevisiae (S) and reconstituted with an AS01 adjuvant (115). The development of vaccines against Toxoplasma gondii (116), T. spiralis (117), Clonorchis sinensis vaccine (118), and T. trichiura (79) have all embraced VLP technology.

Antigens adjuvanted with toll-like receptor (TLR) agonist such as monophosphoryl lipid A (MPLA) and Glucopyransoyl lipid A (GLA) also enhance immune responses by inducing high antibody titres, driving the production of Th1 cytokines and rapid immune responses $(119,120)$. The TLR4 agonists are approved for use in human vaccines and are being studied in leishmaniasis (121), schistosomiasis (122), tuberculosis (123), and influenza vaccines (124). The combination of vaccine antigen with different TLR agonists has also been studied in various 
formulations such as microparticles, nanoparticles, and lipid emulsions to enhance the immune responses induced by the vaccine $(125,126)$. For example, mice immunized with a yellow fever vaccine containing antigens combined with TLR4 and TLR7 agonists and conjugated to synthetic nanoparticles, induced synergistic antigen-specific neutralizing antibodies compared to immunization with antigens coupled with a single TLR ligand (127). Further, an HIV vaccine conjugated with a TLR5 agonist combined to a nanoparticle synthesized from a synthetic poly lactic-co-glycolic acid (PLGA) showed increased immunogenicity in a preclinical mouse model and reduced the immunogenic dose of the vaccine candidate (128). Moreover, the formulation of a TLR4 ligand contained within a PLGA-based nanoparticle plus a malaria proteins (Pfs25) noted for its poor immunogenicity, improved vaccine induced-immunity (129).

Given the range of adjuvants available it is recommended to test several adjuvants or immunostimulants with each potential vaccine antigen at the pre-clinical stage of development in order to optimize the quality of the immune response and to generate effective protective immunity.

\section{Challenges to Vaccine Development}

Having identified a lead antigen and selected an appropriate adjuvant, other hurdles remain to be overcome in the development of an anti-helminth vaccine. These include avoiding unwanted side effects, choosing a suitable animal model for testing immunogenicity and protective immunity, the immunization schedule, and the administration route to shape the immune response induced by the vaccine $(82,83)$.

Beyond the laboratory, other obstacles exist, including geopolitical barriers, unreliable pharmaceutical manufacturer markets, and low industry interest. Further, the rising antivaccine movement in the US and elsewhere have had a significant effect on STHs vaccine development (130). Thus, the development of new vaccines is a complex and multidisciplinary task that requires an understanding of host-pathogen interactions, epidemiology, and manufacturing parameters (131). Most importantly, vaccine researchers must have an understanding of the immune mechanisms involved in diseases and protection in order to select appropriate antigenic targets and delivery systems to shape the immune response induced by the vaccine $(82,83)$.

\section{IMMUNE RESPONSES TO HOOKWORM, ASCARIS, AND TRICHURIS INFECTIONS \\ Th2 Immune Responses Are Center Stage in Acquired Immunity to Infection}

There is an abundance of literature documenting the need for strong Th2 biased immune responses to generate protective immune responses to STHs in animal models $(132,133)$. This is also clear in humans, where immunity to the human hookworms, Ancylostoma duodenale and Necator americanus, the roundworm A. lumbricoides, and the whipworm $T$. trichiura require the generation of strong Th2 immune responses and the production of Th2-associated cytokines including interleukin (IL)-4, IL-5, IL-6, IL-9, and IL-13 (134-136).

Infection of man with $N$. americanus and T. trichiura induces a mixed Th1/Th2 response characterized by the up-regulation of IFN- $\gamma$ (Th1) and a strong Th2 response. As worm burdens decrease with age, or in the context of resistance to reinfection post drug treatment, so parasite-specific IgE levels increase accompanied by Th2 cytokines such as IL-5, IL-9, and IL-13 (134-138). The immune response to A. lumbricoides infection in 12-17 year old hosts living in endemic communities is more Th2 biased (IL-4 and IL-5) with no detectable production of IFN$\gamma$ in response to Ascaris antigens (139-141). Turner et al. (142) divided his study population of Ascaris infected individuals in to two age cohorts, 4-11 year olds and 12-36 year olds. This study concurred with Cooper et al. (139), reporting significant negative correlations between the Th2 cytokines IL-9 and IL13 and infection intensity, but only in the older (over 12) age cohort. Thus, children below the age of 12 showed no inverse correlation between Th2 cytokines and intensity of infection $(134,142)$, suggesting that protection is conferred only after decades of exposure.

Collectively, therefore, there is strong evidence from both animal models and human field studies that any anti-STH vaccine should aspire to promote Th2 immunity.

\section{Identifying the Th2-Controlled Effector Mechanisms}

Exactly how Th2 cytokines culminate in worm expulsion has been debated at length for many years, with our evidence base largely accruing from mouse models where the mechanism of action is best unpicked. Peripheral blood eosinophilia is a hallmark feature of the immune response to helminth infections (143-145). However, is it not clear whether eosinophils kill parasitic worms. IL-5 and eosinophils appear not to be essential for Trichuris and hookworm expulsion, as no difference in worm expulsion was observed following infection of IL-5 knockout mice $(146,147)$. In contrast, early studies demonstrated that eosinophils can kill infected larval stages of most helminth species investigated in vitro in the presence of specific antibodies or complement (148-150). A recent study also showed that eosinophils were recruited to the site of infection by immune serum activated macrophages, leading to the immobilization of migrating A. suum larvae (151).

Several studies have also highlighted a variety of Th2 regulated immune-mediated mechanisms associated with Trichuris expulsion including epithelial cell turn over $(152,153)$, increased muscle hyper-contractility (154), goblet cell hyperplasia and production of mucins (155), with specific Th2 cytokines identified as key. For example, several studies have provided evidence that IL-13, not IL-4 plays a critical role in increasing epithelial cell turnover and in the production of mucins to promote Trichuris worm expulsion (153, 156-159). IL-9 has been shown to be important in the stimulation of intestinal smooth muscle contractility, which drives T. muris expulsion $(154,160)$. In keeping with this, impaired IL-9 expression often results in chronic helminth infection (161). 
Our understanding of mechanisms of immunity to hookworm and roundworm is less well-defined, largely due to the lack of robust mouse models. However, similar Th2-controlled effector mechanisms have been put forward for hookworm (12). For Ascaris, liver-stage immunity during the migratory stages of infection has been associated with oxidative phosphorylation and the production of reactive oxygen species (162), the lung-stage with an eosinophilia $(163,164)$, and expulsion from the gut with increased muscle contractility (165).

The role of the $\mathrm{B}$ cells and antibody in helminth infection remains unclear, with roles embracing both antibody production and antibody-independent cellular regulation. Thus, Bcells may play roles in stimulating the generation and/or polarization of $\mathrm{T}$-cell responses by either cytokine secretion or antigen presentation in addition to their more widely appreciated role in antibody production $(166,167)$. In mouse models, both antibody-dependent and independent roles for the B cell have been proposed. Using a B-cell depletion strategy in a mouse model, a recent study suggested that the development of a Th2 type immune response to Trichuris infection is dependent on the host's genetic background and is independent of antibodies (168). Indeed in the context of Trichuris infections, evidence points toward antibodyindependent worm expulsion mechanisms $(169,170)$. However, for other rodent helminths, roles for antibody have been welldocumented $(171,172)$. For example, parasite-specific IgG1 is thought to play a role in immunity to the rodent hookworm Heligmosomoides polygyrus (173).

In humans, CD11c+ B cells have been shown to be the main IL-10 producers in Indonesian-STH-infected individuals compared to Europeans and Indonesians not exposed to helminths, inferring a regulatory function (174). The robust production of total and parasite-specific IgG1 and IgG4 have been associated with age, but may simply reflect the intensity of helminth infection $(85,134,175)$. For example, children with repeatedly heavy infections with $A$. lumbricoides produced significantly higher levels of $A$. lumbricoides-specific (IgGl, IgG4, and IgE) compared to the repeatedly lightly infected children $(140,176)$. King et al. also suggested that antibody responses may not predict future levels of infection or confer protection from current infection or re-infection with $A$. lumbricoides but may only reflect infection intensity (177). In contrast, Trichuris-specific IgE has been shown to be negatively correlated with infection intensity and positively correlated with age, suggesting that $\operatorname{IgE}$ is associated with protection $(134,136)$. Total levels of IgE have also been correlated with the activation and degranulation of mast cells, basophils, and eosinophils (178). Further, negative associations between hookworm-specific intestinal and serum IgA and hookworm infection were observed in humans and the hamster model of A. ceylanicum hookworm infection, suggesting that antibodies may act in concert with other components of the mucosal and systemic immune response to promote protective immunity against hookworm infection (179-181). Overall, data supports the view that B cells are important in immunity to STHs, but the precise mechanisms by which B-cells and antibody support protective immunity remains only partially understood.

\section{Regulation of Host Immunity by STHs-A Challenge for Vaccine Development}

Experimental model systems, both rodent and human, have demonstrated that helminth infections regulate host immunity, dampening pathology at the expense of efficient worm expulsion. Thus, helminth-derived products have been shown to suppress of Th1/Th17 responses, with suppression associated with the production of IL-10, IL-22 and transforming growth factor- $\beta$ (182, 183). Peripheral blood from hookworm-infected individuals also show higher levels of circulating regulatory $\mathrm{T}$ cells expressing CTLA-4, GITR, IL-10, TGF- $\beta$, and IL-17 than healthy non-infected donors (184). In the context of animal models, mice deficient in IL-10 are susceptible to T. muris infection characterized by elevated levels of IFN- $\gamma$ and TNF$\alpha$, and fatal intestinal pathology (185). Furthermore, depletion of regulatory T-cells during T. muris infection enables worm expulsion at the expense of increased intestinal inflammation (186). In the context of hookworm, and using a mouse model of colitis, A. caninum ES products were shown to suppress colitis. The suppression was associated with potent induction of IL4 and IL-10 by CD4+ T cells in the draining lymph nodes and the colon together with the recruitment of alternatively activated (M2) macrophages and eosinophils to the site of ES administration (187).

Helminth induced immune regulation has been embraced by "worm therapy" advocates (182, 188, 189), and immune regulation by helminths is important in protecting the infected host from potentially life-threatening immunopathology (190, 191). However, the inherent dampening of the immune response associated with chronic worm infections represents a significant challenge in STH vaccine research as well as potentially compromising immunity to other vaccines and influencing the outcome of infection with co-infecting pathogens (192).

\section{UNDERSTANDING HOW VACCINES ELICIT IMMUNITY: CAN WE OVERCOME THE CHALLENGES?}

Vaccination is one of the greatest advances in global health; however, most successful vaccines have been made empirically. Despite a reasonable body of literature from animal models, describing how Th2 immune responses confer protection against STHs in a primary infection, there is very little data regarding the mechanism(s) of vaccine-driven immunity, and this represents a significant gap in our knowledge. Thus, although strong evidence exists to support the need for a vaccine to promote Th2 immune response against STHs in the context of potently regulated environments, how the Th2 immune response culminates in worm expulsion is unknown and may well differ to the Th2 controlled effector mechanisms at play in immunity to a primary infection. Further, we still have little insight into the mechanisms by which vaccines trigger Th1 or Th2 biased immune responses, strong B cell responses or long-lived memory T-cell responses, despite formation of T-cell memory being critical to protection 
against infectious diseases. Antigen delivery to the right antigenpresenting cells is critically important for the quality of the Tcell response, yet targeting of specific populations of antigenpresenting cells is often a neglected aspect in the design of vaccines.

There is a substantial evidence base to support the principle of dendritic targeting in vaccine development (193), although it has not been applied to many vaccines against STHs. Incorporating monoclonal antibodies that recognize, for example, dendritic cell surface molecules into delivery platforms, offers the prospect of direct delivery of antigen to specific antigen-presenting cell subsets in vivo (194-196), thus taking control of the quality of the subsequent vaccine-driven immune response (197). For example, delivery of antigen to CD8+ dendritic cells via Clec9A has been shown to promote CD4 T-cell responses and efficient development of T-follicular helper cells, important in antibody production (198). Interestingly, B-cells have been shown to be the dominant antigen-presenting cell-activating naïve CD4+ Tcells in response to virus-like particles (199), highlighting the importance of understanding how vaccines are presented in vivo as a prerequisite to developing antigen-presenting celltargeting strategies.

\section{SOIL-TRANSMITTED HELMINTH VACCINES: ARE WE GETTING CLOSER?}

\section{Experimental Hookworms Vaccine Candidates}

Hookworms (Necator americanus, Ancylostoma duodenale, and Ancylostoma ceylanicum) infect around 500 million people worldwide and are of significant concern due to their voracious blood-feeding (1). N. americanus and A. duodenale infect humans whereas $A$. ceylanicum and $A$. caninum are zoonotic and rarely infect humans. Hookworms can live for years in the host's small intestine, causing severe iron-deficiency anemia in humans (1).

Pre-clinical hookworm vaccine studies have focused on identifying vaccine antigens from either the dog hookworm A. caninum, A. ceylanicum-golden hamster, or a laboratory strain of $N$. americanus adapted to golden hamsters (46). For example, Miller et al. developed the first hookworm vaccine using whole irradiated A. caninum L3 larvae antigens (200). Dogs immunized with the vaccine candidate showed between 37 and $90 \%$ protection depending on the route of administration $(200,201)$. As a result, this vaccine was commercialized in the United States in 1973 for canines. However, it was withdrawn after 2 years because of the high cost, storage, stability, and the lack of sterilizing immunity (202).

The human hookworm vaccine initiative of the Sabin Product Development Partnership has been directed toward identifying a hookworm vaccine $(49,203)$. Significant efforts have been made in identifying vaccine antigens from the infective larval L3 stages as they play critical roles in host invasion, modulation of host immunity and parasite establishment (203, 204). Several L3 proteins, especially enzymes, showed promising results as recombinant vaccines in different animals, and expression systems, including the tissue invasion-related Astacinlike metalloprotease (Ac-MTP-1) (205-208), Ac-16 (209), and the two Ancylostoma secreted proteins (ASP-1 and ASP-2) (206, 210-212). Of these, ASP-2 was considered a lead hookworm vaccine candidate as it showed the most promising results in animal models and pre-clinical vaccine trials $(206,213,214)$. For example, Bethony et al. showed that laboratory dogs immunized with recombinant ASP-2 formulated with the GlaxoSmithKline Adjuvant (AS03) significantly reduced worm burdens and clinical pathology and induced strong antibody titers compared to control animals (204). Furthermore, the sera obtained from the immunized dogs significantly inhibited the migration of L3 through tissue in vitro compared to sera from control dogs, suggesting that antibodies might play a critical role in protection by decreasing the number of L3 that reach the gastrointestinal tract (204). Rats immunized with Na-ASP-2 formulated with Alhydrogel also induced strong antibody response (IgG1, IgG2a, and $\operatorname{IgM}$ ) and induced a Th2 skewed immune response (215, 216). However, after offering so much promise, the rNa-ASP2/Alhydrogel vaccine was halted in 2008, having reached Phase I clinical trials, due to generalized urticarial reactions characterized by a high prevalence of IgE antibodies to larval antigens in individuals previously infected with or exposed to N. americanus in endemic populations $(202,203,210)$. Thus, the mechanisms of protection from IgE-mediated disorders, typically associated with helminth infection, seemed unable to protect adults living in hookworm endemic areas from developing allergic reactions after immunization with Na-ASP-2. It was hypothesized that the induced immediate-type hypersensitivity was due to the intrinsic structural or biological properties of the Na-ASP-2 molecule $(217,218)$.

\section{The Identification of Aspartic Protease-Hemoglobinase (Na-APR-1) and Glutathione S-Transferase-1 (Na-GST-1) as Lead Antigens}

The failure of Phase I clinical trial focused attention back on to antigen selection and led scientists toward identifying vaccine antigens that were less likely to be recognized by IgE antibodies induced by the natural infection (49). Strategies included examining IgE responses in the sera from populations in countries with endemic STH infections, mutating the antigenic epitopes recognized by host IgE and using bioinformatics tools that can screen for allergenicity $(212,219)$. Adult hookworms suck blood from damaged vessels in the gut mucosa and digest hemoglobin using haemoglobinases (220, 221). Since neutralization of these critical enzymes would result in starvation of the parasites, leading to parasite death, these antigens were selected for the development of hookworm vaccines $(49,222)$. Two promising vaccines derived from the adult stage parasite were identified, aspartic protease-hemoglobinase (Na-APR-1) and glutathione S-transferase-1 (Na-GST-1) (203, 222, 223). APR is an enzyme that helps digest hemoglobin $(221,224)$, whereas GST is essential for parasite survival and heme detoxification (Blood-feeding pathway) $(48,225)$.

In pre-clinical testing, recombinant Na-APR-1 induced neutralizing antibodies (IgG1 and IgG2) against the hookworm 
haemoglobinase and resulted in significantly reduced blood loss, adult parasite burdens, and fecal egg counts in immunized dogs when challenged with hookworm larval (222, 224). Likewise, hamsters immunized with Ac-APR-1 showed a high level of protection (226). Importantly, IgE from individuals with hookworm infections did not recognize Na-APR-1 (224). Developing APR further as a lead antigen, Skwarczynski et al. developed an epitope-based subunit vaccine based on the $\mathrm{A}_{291} \mathrm{Y}$ B-cell epitope identified from the Na-APR-1, incorporated into a self-adjuvant system (Lipid Core Peptide). Interestingly, the vaccine candidate induced potent enzyme-neutralizing antibodies in mice (227). However, this study did not assess the protective immune response in vivo. Pearson et al. also explored a multi-antigen peptide-based vaccine against schistosomiasis and hookworm containing $\mathrm{A}_{291} \mathrm{Y}$ peptide from Na-APR-1, a S. mansoni Sm-tetraspanin-2 and Na-GST-1 antigens (228). A more recent study also showed that mice immunized with a lipopeptide-based vaccine consisting of a B-cell epitope (p3) derived from the Na-APR-1 and attached to a T-helper epitope (p25) induced a strong humoral immune response and resulted in $>98 \%$ reduction in worm and egg burden following challenge infection with the rodent model hookworm, Nippostrongylus brasiliensis (229). Further, the same vaccine nanoparticle, when incorporated into natural and unnatural hydrophobic amino acids, also significantly reduced both worm and egg burden in orally vaccinated mice following $N$. brasiliensis challenge without the need for adjuvant (93). Pre-clinical studies also suggested that GSTs from $N$. americanus, A. caninum, or A. ceylanicum to be promising vaccine candidates (230). For example, NaGSTs from the dog hookworm A. caninum (Ac-GST-1) elicited a significant reduction in adult hookworm burdens following challenge infection compared to control animals $(225,231)$.

On the basis of these and other pre-clinical data, the two lead vaccine candidates (Ac-GST-1 and Ac-APR-1) formulated individually with Th2 adjuvant Alhydrogel and TLR4 agonist (GLA) are in Phase 1 trials in the United States, Brazil, and Africa $(48,232,233)$. Co-administration of both vaccines is also undergoing a clinical trial in Gabon (234).

\section{Other Hookworm Vaccine Candidates}

Promising results have also been achieved in hamsters immunized with DNA-based vaccines encoding the $A$. ceylanicum metalloprotease 6 (Ace-MEP-6) (63) or Ace-MEP-7 as an alternative strategy to recombinant protein production (62). Both vaccines induced significant reductions in worm burden. Additionally, a 78\% egg count reduction was observed in hamsters immunized with Ace-MEP-7 (62).

Recent genomic and transcriptomic analysis of all three species of hookworms $(26,29,30)$ have also helped to identify additional vaccine candidates including the two intestinally-enriched, putatively secreted, cathepsin B cysteine proteases (AceyCP1, AceyCPL) and the Kunitz-type protease inhibitor (AceySKPI3) (29). Vaccination of hamsters with AceyCP1/Alhydrogel induced a high level of protection associated with the production of high levels of antigen-specific antibodies (IgG). These antibodies also reduced the motility of the adult worms in vitro and induced Th2 responses (IL-4, IL-5, and IL-13) in re-stimulated splenocytes (235). Mechanistically, vaccinated animals were thought to be protected as a result of antibodies that neutralized the catalytic activity of the hookworm antigens in the gut $(224,236)$, although the full mechanism through which protection is conferred remains unclear. This study and others proved that parasite-secreted cysteine proteases involved in parasite nutrition are valid targets for the development of anti-parasitic vaccines (236). Table 1 summarizes candidate hookworm vaccine antigens.

In the context of human hookworm vaccine development, the existence of a human model system for the testing of hookworm vaccines is a significant advantage. Thus, controlled human hookworm infections will likely improve the early stages of vaccine efficacy testing (50).

\section{Experimental Ascaris Vaccine Candidates}

Ascariasis caused by Ascaris lumbricoides, or Ascaris suum remains the most prevalent NTD worldwide. Indeed, the use of Ascaris egg-contaminated sewage sludge in agriculture has meant that, even in Europe, exposure to Ascaris is surprisingly common (237-239). A. lumbricoides infects around 819 million people worldwide, with children especially susceptible (240). A. suum, the pig roundworm, causes serious economic losses in meatproducing livestock species worldwide (241). Both parasites have a cosmopolitan distribution, an identical life cycle and are morphologically, genetically, and antigenically very similar (242245). Consequently, efforts have been made in the past to identify vaccine antigens derived from the larval stages and ultraviolet irradiated attenuated embryonated eggs of the pig roundworm $A$. suum (246). However, the large size of the pigs, the cost and the complexities of animal husbandry, has driven many researchers to use mice and other rodent hosts as a convenient alternative for purposes of vaccine development (247). However, it is important to note that there is no rodent model that enables the Ascaris parasite to complete its life cycle.

Over the last decade, efforts have been made to identify crude extracts (248), recombinant proteins $(249,250)$, defined native molecules (251) and extracellular vesicles (252) as potential Ascaris vaccine candidates. These include the $66 \mathrm{kDa}$ gut antigenic protein, the most immunodominant protein identified from homogenized A. suum adult worm fractions (251), but which was never tested in vivo for immunoprophylactic purposes (251). Other studies have explored targeting nematode haemoglobins as they can break down nitric oxide and hydrogen peroxide, thus potentially providing protection against innate host defenses $(253,254)$. However, immunizing pigs with $A$. suum hemoglobin (AsHb) in combination with QuilA adjuvant, failed to induce protective immunity following A. suum egg challenge (255).

Further, targeting nematode haemoglobins may offer cross species protection. For example, passive immunization of mice with a monoclonal antibody (48Eg) against hemoglobin of the nematode Anisakis pegreffii prior to infection with Nippostrongylus brasiliensis (rodent hookworm) enhanced protective Th2 immunity and significantly reduced worm burdens (256). This study also showed that $48 \mathrm{Eg}$ cross-reacts with the hemoglobin of several nematodes including $A$. 
TABLE 1 | Major hookworm vaccine candidates.

\begin{tabular}{|c|c|c|c|c|c|c|}
\hline Antigen & Parasite spp. & Adjuvant & Animal model & Vaccine type & Protection \% & References \\
\hline $\begin{array}{l}\text { Glutathione-S } \\
\text { transferase } 1 \\
\text { (GST-1) }\end{array}$ & $\begin{array}{l}\text { A. caninum } \\
\text { (Ac-GST-1) }\end{array}$ & Alhydrogel & $\begin{array}{l}\text { Mesocricetus auratus } \\
\text { golden hamsters }\end{array}$ & r-protein & $50.6 \%$ reduction in worm burden & $(226)$ \\
\hline \multirow[t]{3}{*}{$\begin{array}{l}\text { Aspartic protease } 1 \\
\text { (APR-1) }\end{array}$} & $\begin{array}{l}\text { N. americanus } \\
\text { (Na-APR-1) }\end{array}$ & $\begin{array}{l}\text { Alhydrogel and a } \\
\text { CpG }\end{array}$ & Dogs & r-protein & $\begin{array}{l}\text { ND } \\
66.6 \% \text { reduction in egg count }\end{array}$ & $(224)$ \\
\hline & $\begin{array}{l}\text { A. caninum } \\
\text { (Ac-APR-1) }\end{array}$ & ASO3 & Dogs & r-protein & $33 \%$ reduction in worm burden & $(222)$ \\
\hline & $\begin{array}{l}\text { A. caninum } \\
\text { (Ac-APR-1) }\end{array}$ & Alhydrogel & $\begin{array}{l}\text { Mesocricetus auratus } \\
\text { golden hamsters }\end{array}$ & r-protein & $44.4 \%$ reduction in worm burden & $(226)$ \\
\hline \multirow[t]{2}{*}{$\begin{array}{l}\text { Metalloprotease } 6 \text { and } 7 \\
\text { (MEP-6 and MEP-7) }\end{array}$} & $\begin{array}{l}\text { A. ceylanicum } \\
\text { (AceyMEP-6) }\end{array}$ & ND & Syrian golden hamsters & DNA-based & $80 \%$ reduction in worm burden & (63) \\
\hline & $\begin{array}{l}\text { A. ceylanicum } \\
\text { (AceyMEP-7) }\end{array}$ & ND & Syrian golden hamsters & DNA-based & $\begin{array}{l}50 \% \text { reduction in worm burden } \\
78 \% \text { reduction in egg count }\end{array}$ & $(62)$ \\
\hline \multirow[t]{2}{*}{$\begin{array}{l}\text { Cysteine proteases } 1 \\
\text { and } 2 \\
(\mathrm{CP}-1 \text { and } \mathrm{CP}-2)\end{array}$} & $\begin{array}{l}\text { A. ceylanicum } \\
\text { (AceyCP1) }\end{array}$ & Alhydrogel & Syrian golden hamsters & r-protein & $\begin{array}{l}40-54 \% \text { reduction in worm } \\
\text { burden } \\
54-60 \% \text { reduction in egg count }\end{array}$ & $(235)$ \\
\hline & $\begin{array}{l}\text { N. americanus } \\
\text { (Na-CP-2) }\end{array}$ & Freund & $\begin{array}{l}\text { Mesocricetus auratus } \\
\text { golden hamsters }\end{array}$ & r-protein & $29.3 \%$ reduction in worm burden & $(226)$ \\
\hline
\end{tabular}

ND, Not done; r-protein, Recombinant protein.

lumbricoides, N. brasiliensis, Anisakis pegreffii, Pseudoterranova decipiens, and Contracaecum spp.

The public availability of the genome, and gene expression data for both A. lumbricoides and A. $\operatorname{suum}(28,243,245)$, also helped in identifying Ascaris vaccine peptides based on the RV approach. Indeed a recent study identified CD4 Th cell epitopes in A. suum ES products based on in vitro antigen processing and quantitative proteomic tools (257). However, the selected epitopes have yet to be tested in vitro or in vivo for their ability to induce immune responses.

To date the five major $A$. suum immunodominant antigens tested as possible vaccine candidates are; $A$. suum 16-kilodalton As16 (249), As14 (258), As24 (259), As37 (260), and As-Enol (enolase) (247). As14 and As16, identified from the sera of infected mice with A. suum, are localized in both larval and adult stages, as well as in the ES products of both the human and pig roundworms (23) and are homologous to the A. ceylanicum (Ac16) vaccine candidate (209). Intranasal immunization of mice with recombinant rAs14 (258) and rAs16 (249) expressed in E. coli and coupled with cholera toxin B subunit (CTB), produced significant protection (64 and 58\% respectively), compared to non-vaccinated mice following $A$. suum infection. Furthermore, recombinant rAs16 induced a 58\% reduction in the recovery of the lung-stage in a pig animal model, associated with high levels of IL-4 and IL-10 and high titers of rAs16-specific mucosal IgA and serum IgG antibody (261). Through the use of sera from rAs16-CTB immunized mice, As16 was localized to the worm hypodermis and intestine $(249,261)$. Sera from $r$ As16-CTB immunized mice was also shown to inhibit molting of $A$. suum L3 in vitro (261). Interestingly, subcutaneous vaccination of mice with yeast-expressed As16 formulated with Montanide ISA720 adjuvant significantly reduced larval recovery and induced a Th2 immune response against challenge infection. In contrast mice immunized with rAs14 formulated with ISA720 failed to induce protection (262). Other studies have used plants as alternative, attractive, vaccine producing factories. For example, mice fed with As16-transgenic rice fused with CTB showed a significant reduction in the number of larvae following challenge infection (263).

Promising results were seen in mice immunized with the nematode-specific protein (As24) expressed in E. coli and emulsified with Freund's Complete Adjuvant (FCA), although the potential for translating these studies to man is limited by the choice of adjuvant. The vaccine resulted in a $58 \%$ reduction in lung larval burden post-challenge and induced a Th1/Th2mixed type immune response characterized by elevated levels of IgG, IFN- $\gamma$ and IL-10 (264). As24 homologous proteins were also identified in Ascaris lumbricoides and the dog parasitic nematode Toxocara canis (259). Anti-As24 IgG also inhibited molting of A. suum lung stage, suggesting As24 plays a critical role in the development of Ascaris larvae (259). Further, the protective immune response to $A$. suum larvae correlated with the induction of IgG1 and IgM, and not with IgG2 in pigs immunized with As14, and As24 fractions from adult worms $(265,266)$.

It has also been proposed that As37, a member of the immunoglobulin superfamily, identified from the adult and larval stages as well as in the hypodermis and muscle of A. suum is a potential Ascaris vaccine candidate $(260,267)$. Mice immunized with $\mathrm{rAs} 37$ formulated with AddaVax adjuvant induced a significant $49.7 \%$ larval worm reduction after challenge infection compared to control animals. Protection was associated with the production of high levels of serological IgG1 and IgG2a and stimulated the production of IL-4, IL5, IL-10, and IL-13 cytokines, suggesting that both Th1 and Th2 immune responses are essential for worm expulsion (250). Interestingly, the AddaVax adjuvant performed better than the Th1 adjuvant MPLA and the Th2 adjuvant Alhydrogel. Remarkably, sequence analysis revealed that As37 is highly conserved in other STHs 
including $N$. americanus, A. ceylanicum, A. caninum, and $T$. muris, but not in humans, suggesting that the nematodeconserved antigen could serve as a pan-helminth vaccine antigen (250).

The inorganic A. suum pyrophosphatase is another promising vaccine candidate expressed throughout the life cycle and localized in the surface and adult reproductive tissues (268). Knockdown of A. suum pyrophosphatase by RNAi has indicated the importance of this phosphatase in larval development and molting (269). Furthermore, immunization of mice with rAsPPase expressed in E. coli, and formulated with TiterMax Gold adjuvant resulted in $>70 \%$ protection against the $\mathrm{L} 3$ stage, drove a high serum IgG1 response, and significant production of splenic IL-10 (270, 271).

Moreover, enolase (As-Enol-1), found in the A. suum larva, adult ES and EVs has been shown to play a critical role in larval development $(272,273)$, and triggering in vitro macrophage nitric oxide production (274). Vaccination of Kunming mice with recombinant As-Enol-1 leads to a $61.13 \%$ reduction $(P<0.05)$ in larval recovery and elicits a Th1/Th2 (IFN- $\gamma$, IL-2, IL-4, and IL-10) immune response (247).

Gazzinelli-Guimaraes et al. (248) also evaluated the immunological, potential clinical impact and protective immune responses of three different Ascaris extract vaccines formulated with the MPLA adjuvant. Mice immunized with crude extract of adult worm (ExAD) exhibited a significant reduction (51\%) in the total number of migrating larvae recovered in the lung tissue and bronchoalveolar lavage; crude extract of adult worm cuticle (CUT) 59\%, and crude extract of infective larvae (L3) (ExL3) 61\% compared to the non-immunized mice. Protection was associated with a marked systemic production of Ascarisspecific IgG1 and IgG3 subclasses and a significant increase in systemic IL-5 and IL-10 (pre-challenge) and lung IL-10 (postchallenge). ExL3 and CUT protection was also associated with less tissue damage and pulmonary tissue inflammation as well as reduced pulmonary dysfunction following Ascaris challenge. Furthermore, the passive transfer of purified antigen-specific IgG antibodies from mice immunized with ExL3, CUT, and ExAD into naïve mice induced a significant reduction in parasite burdens in lungs of 65,64 , and $64 \%$, respectively (248). These results suggest that vaccine induced antibodies play a crucial role in reducing larval migration and subsequent larval burden in the lungs.

Overall, the protective anti-Ascaris immunity (Table 2) observed in all the experimental animal model points toward a Th2-biased immune response, associated with the production of high levels of parasite-specific IgG1. Analyses of vaccine-driven immunity has suggested more mixed Th1/Th2 immune responses may be at play (250); however, over robust Th1-type responses are counter protective. Again, as with hookworm, the immunological mechanisms underpinning vaccine induced immunity to Ascaris infections are only partially understood.

\section{Experimental Trichuris Vaccine Candidates}

Historically, the global health community have focused their vaccine research on hookworm and ascariasis and somewhat
TABLE 2 | Major Ascaris vaccine candidates.

\begin{tabular}{lllc}
\hline Antigen & $\begin{array}{l}\text { Vaccine } \\
\text { type }\end{array}$ & $\begin{array}{l}\text { Protection \% (Reduction } \\
\text { in lung larval burden) }\end{array}$ & References \\
\hline As14 & r-protein & $64 \%$ & $(258,266)$ \\
As16 & r-protein & $58 \%$ & $(249,261$, \\
& & & $262)$ \\
As24 & r-protein & $58 \%$ & $(259,264)$ \\
As37 & r-protein & $69 \%$ & $(275)$ \\
As42 & r-protein & $67 \%$ & $(266)$ \\
Enol-1 & DNA & $61 \%$ & $(247)$ \\
As66k & ND & ND & \\
- Crude extract of & Crude & $\bullet$ ExAD 51\% $(p<0.01)$ & \\
$\begin{array}{l}\text { adult worm (ExAD) } \\
\text { Crude extract of }\end{array}$ & extract & $\bullet$ CUT 59\% $(p<0.001)$ & \\
$\begin{array}{l}\text { adult worm cuticle } \\
\text { (CUT) }\end{array}$ & & $\bullet$ ExL3 61\% $(p<0.001)$ & \\
- Crude extract of & & & \\
infective larvae & & & \\
(L3) (ExL3) & & &
\end{tabular}

ND, Not done; r-protein, Recombinant protein.

TABLE 3 | Major Trichuris vaccine candidates.

\begin{tabular}{|c|c|c|c|}
\hline Antigen/adjuvant & $\begin{array}{l}\text { Vaccine } \\
\text { type }\end{array}$ & $\begin{array}{l}\text { Protection \% } \\
\text { (Reduction in } \\
\text { worm burden) }\end{array}$ & References \\
\hline ES/FIA & Crude & $97 \%$ & (85) \\
\hline EVs and EVs fractions & Crude & $\begin{array}{l}\text { Significant } \\
\text { reduction (\% was } \\
\text { not indicated) }\end{array}$ & $(276)$ \\
\hline rPP2AVOVS & r-protein & $97.90 \%$ & $(277)$ \\
\hline $\begin{array}{l}\text { - } \text { rTm-WAP49/Montanide ISA } \\
720 \\
\text { - } \text { rTm-WAP-F8+Na-GST- } \\
\text { 1/Montanide } \\
\text { ISA } 720\end{array}$ & r-protein & $\begin{array}{l}\text { - } 48 \% \\
\text { - } 38 \%\end{array}$ & $(91)$ \\
\hline $\begin{array}{l}\text { VLPs expressing Trichuris T-cell } \\
\text { epitopes }\end{array}$ & $\begin{array}{l}\text { Epitope- } \\
\text { based }\end{array}$ & $50 \%$ & (79) \\
\hline
\end{tabular}

OVS, Oleic-vinyl sulfone; FIA, Freund's incomplete adjuvant.

neglected trichuriasis, despite the fact that trichuriasis is the second most common STH infection after ascariasis (13). Around 477 million people are estimated to be infected with Trichuris infection, with the highest intensity of infection seen in schoolaged children $(1,2)$.

One of the first attempts at identifying a non-living vaccine for T. trichiura was conducted in the mouse model T. muris, using adult and larval worm somatic antigens to stimulate protective immunity in infected animals (278). Vaccination of mice with T. muris somatic antigens that were isolated from $\mathrm{NIH}$ mice and emulsified in Freund's incomplete adjuvant stimulated protective immunity and a $92 \%$ reduction in worm burden after infection (278). Wakelin and Selby (278) also demonstrated that soluble antigens from the anterior region of adult worms were more effective in stimulating immunity than antigens prepared from the posterior region. T. muris adult worm homogenate and ES products from both adult and larval stages have been used in early-stage vaccine development $(279,280)$. Route of 
antigen delivery has also been explored. For example, a level of protection can be achieved against T. muris using homogenized adult antigens combined with cholera toxin as an oral vaccine (281). However, a $100 \%$ reduction in worm burden can be achieved through subcutaneous (s.c.) vaccination with adult antigens emulsified in Freund's complete adjuvant (281). Moving to slightly less crude antigen preparations, but also exploring the route of administration, Jenkins and Wakelin (279) showed that vaccinating mice subcutaneously with $100 \mu \mathrm{g}$ of the excreted and secreted ES products of adult T. muris parasites without adjuvant, was more effective than intraperitoneal vaccination, also in the absence of adjuvant. More recently, Dixon et al. (85) showed that subcutaneous vaccination of naturally susceptible AKR mice with T. muris ES emulsified with Freund's incomplete adjuvant (IFA) induced expulsion of a high-dose infection. This study also described priming of the immune response to subcutaneous vaccination as occurring in peripheral lymph nodes draining the site of vaccination, that the ensuing protective immune response was of a mixed Th1/Th2 type and eluded to the effector mechanisms involving some form of intestinal antibodymediated cellular immune response (85).

Interest in identifying host protective material in the extracellular vesicle (EV) components within helminth secretions has increased recently (282-284). For example, Shears et al. $(276,285)$ showed that vaccinating C57BL/6 mice with either ES fractions or EVs isolated from T. muris without an adjuvant and prior to infection with a low-dose of T. muris eggs significantly reduced the worm burden compared to the PBS-injected group, inducing a mixed Th1/Th2 response. Vaccination of mice with ES fractions stimulated long-lasting protection against chronic infection characterized by the production of high levels of IL-9 and IL-13. However, the sera from ES vaccinated mice did not protect naïve mice from $T$. muris chronic infection, suggesting that anti-parasite antibodies did not play a critical role in protection (285). Shears et al. also demonstrated that vaccination with EVs boosted IgG1 antibody production against T. muris ES proteins, suggesting that there is extensive overlap in protein content between the EVs and ES (276).

Gomez-Samblas et al. (277) have also identified a vaccine candidate that potentially could work against a variety of helminth parasites, including T. muris. This candidate is based on the recombinant serine/threonine phosphatase $2 \mathrm{~A}$ from the nematode Angiostrongylus costaricensis (rPP2A), formulated as a lipopeptide and conjugated with a self-adjuvant oleic-vinyl sulfone (OVS). Interestingly, intranasal immunization of AKR mice with the vaccine candidate prior to T. muris challenge led to a marked reduction in the number of adult parasites. The immunized mice also developed a combined Th17/Th9 response orchestrated by the cytokines IL-25, IL-17, and IL-9 (277). The same vaccine candidate has also been tested in lambs and was found to provide significant protection against the ovine helminth Haemonchus contortus and Teladorsagia circumcincta infection (286).

Briggs et al. (91) had developed two vaccines against trichuriasis based on T. muris whey acidic protein (rTm-WAP49) and T. muris WAP fragment fusion protein (rTm-WAPF8+Na-GST-1) formulated with Montanide ISA 720 adjuvant.
Vaccinating AKR mice with the vaccine candidates three times at 2-week intervals prior to T. muris challenge induced a partial reduction in worm burden (48 and 38\%, respectively) (91). The authors also showed that both humoral and cellular immune responses were induced and characterized by elevated antigenspecific IgG1 and IgG2c antibodies and Th2 (IL-4, IL-9, and IL13) cytokines in the draining inguinal LNs, draining mesenteric LNs and spleens of vaccinated mice (91).

Despite these promising results (Table 3), subunit vaccines often require substantial adjuvant and often do not provide sufficient protective cellular immunity compared with other vaccine approaches (76). Thus, a recent study identified a promising vaccine candidate based on major histocompatibility complex class II (MHC-II) T-cell epitopes identified from the whole genome of the Trichuris, incorporated into Hepatitis B core antigen VLP (79). The four epitopes were identified from chitin-binding domain-containing proteins and chymotrypsinlike serine proteases. In vitro studies showed that the VLPs were internalized and co-localized in the antigen-presenting cells (dendritic cells and macrophages) lysosomes and stimulated the production of pro-inflammatory and anti-inflammatory cytokines. Remarkably, immunization of mice with four VLPs expressing Trichuris T-cell epitopes induced a significant reduction in worm burden following challenge infection compared to control animals without the need for an adjuvant. Protection was associated with the induction of a mixed Th1/Th2 immune response characterized by the production of Trichurisspecific IgM and IgG2c and the production of mesenteric lymph node-derived Th2 cytokines and goblet cell hyperplasia.

\section{CONCLUSION AND LESSONS LEARNED}

STH infections are common in the world's poorest people living in low- and middle-income countries and are linked to detrimental effects on maternal and child health. Several studies have been conducted over the years to develop vaccines as cost-effective methods to control STHs infection (49). However, the process of vaccines development against STH parasites is complicated and faces several challenges. Thus, multiple broadranging factors have to be taken in to account when developing a protective vaccine to meet the immunogenicity, safety, and efficacy criteria of regulatory institutes such as the US Food and Drug Administration. These include identifying protective antigens that do not trigger unwanted allergic-type immune responses, the best route of administration, the vaccine type and adjuvant to be used and how to elicit protective immunity in the face of regulated immune environments typical of chronic STH infections (287). Underpinning all these factors is a need to understand the immune response induced by STHs and the nature of vaccine-driven protective immune responses, such that one can strategically design vaccines to drive the right sort of quality of immune response in susceptible hosts. There is a significant problem in vaccinology in that subunit vaccines, which are composed of antigenic proteins, are often poorly immunogenic and fail to stimulate memory immune responses. Furthermore, there is a knowledge gap in understanding the 
mechanisms of action of vaccines and how they stimulate the required $\mathrm{T}$ - and $\mathrm{B}$-cell responses. Targeting of antigen to specific antigen-presenting cell subsets is a promising strategy going forward. Coupling of a monoclonal antibody to antigen poses technical challenges, requiring fusion protein engineering or cross-linking, both of which can fail or produce low yields. However, overcoming these technical barriers is likely to be far-reaching in the context of STHs, where vaccine delivery is likely to occur in the context of pre-existing chronic infections. Despite an increase in STH vaccine research, it remains a disappointing truth that no human anti-STH vaccine currently exists. Among the lessons learned over the last decade is the importance of gaining international pharma company attention and support in order to bring antihelminth vaccines to trials. Further, raising public health awareness of the enormous threat presented by STH infections to the economy and health of atrisk populations, including their impact on susceptibility to other

\section{REFERENCES}

1. Truscott JE, Turner HC, Farrell SH, Anderson RM. Soil-transmitted helminths: Mathematical models of transmission, the impact of mass drug administration and transmission elimination criteria. Adv Parasitol. (2016) 94:133-98. doi: 10.1016/bs.apar.2016.08.002

2. Pullan RL, Smith JL, Jasrasaria R, Brooker SJ. Global numbers of infection and disease burden of soil transmitted helminth infections in 2010. Parasit Vectors. (2014) 7:37. doi: 10.1186/1756-3305-7-37

3. Kassebaum NJ, Arora M, Barber RM, Bhutta ZA, Brown J, Carter A, et al. Global, regional, and national disability-adjusted life-years (DALYs) for 315 diseases and injuries and healthy life expectancy (HALE), 1990-2015: a systematic analysis for the global burden of disease study 2015. Lancet. (2016) 388:1603-58. doi: 10.1016/S0140-6736(16)31460-X

4. Farrell SH, Coffeng LE, Truscott JE, Werkman M, Toor J, de Vlas SJ, et al. Investigating the effectiveness of current and modified world health organization guidelines for the control of soil-transmitted helminth infections. Clin Infect Dis. (2018) 66(Suppl. 4):S253-9. doi: 10.1093/cid/ciy002

5. Freeman MC, Akogun O, Belizario V Jr, Brooker SJ, Gyorkos TW, Imtiaz $\mathrm{R}$, et al. Challenges and opportunities for control and elimination of soiltransmitted helminth infection beyond 2020. PLoS Negl Trop Dis. (2019) 13:e0007201. doi: 10.1371/journal.pntd.0007201

6. Forrer A, Khieu V, Vounatsou P, Sithithaworn P, Ruantip S, Huy R, et al. Strongyloides stercoralis: spatial distribution of a highly prevalent and ubiquitous soil-transmitted helminth in cambodia. PLoS Negl Trop Dis. (2019) 13:e0006943. doi: 10.1371/journal.pntd.0006943

7. Kumar NP, Kathamuthu GR, Moideen K, Banurekha VV, Nair D, Fay $\mathrm{MP}$, et al. Strongyloides stercoralis coinfection is associated with greater disease severity higher bacterial burden and elevated plasma matrix metalloproteinases in pulmonary tuberculosis. J Infect Dis. (2020) 222:10216. doi: 10.1093/infdis/jiaa194

8. Schär F, Trostdorf U, Giardina F, Khieu V, Muth S, Marti H, et al. Strongyloides stercoralis: global distribution and risk factors. PLoS Negl Trop Dis. (2013) 7:e2288. doi: 10.1371/journal.pntd.0002288

9. Vasquez-Rios G, Pineda-Reyes R, Pineda-Reyes J, Marin R, Ruiz EF, Terashima A. Strongyloides stercoralis hyperinfection syndrome: a deeper understanding of a neglected disease. J Parasit Dis. (2019) 43:167-75. doi: 10.1007/s12639-019-01090-x

10. Breloer M, Abraham D. Strongyloides infection in rodents: immune response and immune regulation. Parasitology. (2017) 144:295-315. doi: $10.1017 /$ S0031182016000111 pathogens $(49,192)$ is critical. This has never been more relevant than now, given today's climate of emerging infectious diseases including SARS-CoV-2.

\section{AUTHOR CONTRIBUTIONS}

AZ researched the literature, drafted the manuscript, and compiled the tables. KE edited the manuscript and revised the content. All authors contributed to the article and approved the submitted version.

\section{FUNDING}

KE's Laboratory was supported by grants from both the Medical Research Council UK grant MR/NO22661/1 (https://mrc.ukri. org/) and Biotechnology and Biological Sciences Research Council grant BB/P018157/1 (https://bbsrc.ukri.org/).

11. Nutman TB. Human infection with strongyloides stercoralis and other related strongyloides species. Parasitology. (2017) 144:263-73. doi: 10.1017/S0031182016000834

12. Loukas A, Hotez PJ, Diemert D, Yazdanbakhsh M, McCarthy JS, CorreaOliveira R, et al. Hookworm infection. Nat Rev Dis Prim. (2016) 2:16088. doi: $10.1038 / \mathrm{nrdp} .2016 .88$

13. Else KJ, Keiser J, Holland CV, Grencis RK, Sattelle DB, Fujiwara RT, et al. Whipworm and roundworm infections. Nat Rev Dis Prim. (2020) 6:44. doi: 10.1038/s41572-020-0171-3

14. Eshetu T, Aemero M, Jejaw A. Efficacy of a single dose versus a multiple dose regimen of mebendazole against hookworm infections among school children: a randomized single-blinded trial. BMC Infect Dis. (2020) 20:376. doi: 10.1186/s12879-020-05097-1

15. WHO. Soil-Transmitted Helminthiasis: Deworming Campaign Improves Child Health School Attendance in Rwanda. Geneva: WHO Library (2015).

16. Haldeman MS, Nolan MS, Ng'habi KR. Human hookworm infection: is effective control possible? A review of hookworm control efforts and future directions. Acta Trop. (2020) 201:105214. doi: 10.1016/j.actatropica.2019.105214

17. Nery SV, Pickering AJ, Abate E, Asmare A, Barrett L, Benjamin-Chung J, et al. The role of water, sanitation and hygiene interventions in reducing soiltransmitted helminths: interpreting the evidence and identifying next steps. Parasit Vectors. (2019) 12:273. doi: 10.1186/s13071-019-3532-6

18. Jia TW, Melville S, Utzinger J, King CH, Zhou XN. Soil-transmitted helminth reinfection after drug treatment: a systematic review and metaanalysis. PLoS Negl Trop Dise. (2012) 6:e1621. doi: 10.1371/journal.pntd. 0001621

19. Furtado LFV, da Silva Medeiros C, Zuccherato LW, Alves WP, de Oliveira VNGM, da Silva VJ, et al. First identification of the benzimidazole resistance-associated F200Y SNP in the beta-tubulin gene in ascaris lumbricoides. PLoS ONE. (2019) 14:e0224108. doi: 10.1371/journal.pone. 0224108

20. Matamoros G, Rueda MM, Rodríguez C, Gabrie JA, Canales M, Fontecha $\mathrm{G}$, et al. High endemicity of soil-transmitted helminths in a population frequently exposed to albendazole but no evidence of antiparasitic resistance. Trop Medi Infect Dis. (2019) 4:73. doi: 10.3390/tropicalmed4020073

21. Becker SL, Liwanag HJ, Snyder JS, Akogun O, Belizario V Jr, Freeman MC, et al. Toward the 2020 goal of soil-transmitted helminthiasis control and elimination. PLoS Negl Trop Dis. (2018) 12:e0006606. doi: 10.1371/journal.pntd.0006606

22. Hotez PJ. The rise or fall of neglected tropical diseases in East Asia Pacific. Acta Trop. (2020) 202:105182. doi: 10.1016/j.actatropica.2019.105182 
23. Zhan B, Beaumier CM, Briggs N, Jones KM, Keegan BP, Bottazzi ME, et al. Advancing a multivalent 'Pan-anthelmintic'vaccine against soiltransmitted nematode infections. Expert Rev Vaccines. (2014) 13:321-31. doi: 10.1586/14760584.2014.872035

24. Claerebout E, Geldhof P. Helminth vaccines in ruminants: from development to application. Vet Clin Food Anim Pract. (2020) 36:159-71. doi: 10.1016/j.cvfa.2019.10.001

25. Hagel I, Giusti T. Ascaris lumbricoides: an overview of therapeutic targets. Infect Disord Drug Targets. (2010) 10:349-67. doi: 10.2174/187152610793180876

26. Consortium IHG. Comparative genomics of the major parasitic worms. Nat Genet. (2019) 51:163-74. doi: 10.1038/s41588-018-0262-1

27. Foth BJ, Tsai IJ, Reid AJ, Bancroft AJ, Nichol S, Tracey A, et al. Whipworm genome and dual-species transcriptome analyses provide molecular insights into an intimate host-parasite interaction. Nat Genet. (2014) 46:693-700. doi: 10.1038/ng.3010

28. Jex AR, Liu S, Li B, Young ND, Hall RS, Li Y, et al. Ascaris suum draft genome. Nature. (2011) 479:529-33. doi: 10.1038/nature10553

29. Schwarz EM, Hu Y, Antoshechkin I, Miller MM, Sternberg PW, Aroian RV. The genome and transcriptome of the zoonotic hookworm ancylostoma ceylanicum identify infection-specific gene families. Nat Genet. (2015) 47:416-22. doi: 10.1038/ng.3237

30. Tang YT, Gao X, Rosa BA, Abubucker S, Hallsworth-Pepin K, Martin J, et al. Genome of the human hookworm necator americanus. Nat Genet. (2014) 46:261-9. doi: 10.1038/ng.2875

31. De Sousa KP, Doolan DL. Immunomics: a 21st century approach to vaccine development for complex pathogens. Parasitology. (2016) 143:23644. doi: 10.1017/S0031182015001079

32. Bain R. Irradiated vaccines for helminth control in livestock. Int J Parasitol. (1999) 29:185-91. doi: 10.1016/S0020-7519(98)00187-8

33. Miller TA. Industrial development and field use of the canine hookworm vaccine. Adv Parasitol. (1978) 16:333-42. doi: 10.1016/S0065-308X(08)60577-1

34. Abuzeid AM, Zhou X, Huang Y, Li G. Twenty-five-year research progress in hookworm excretory/secretory products. Parasit Vectors. (2020) 13:136. doi: 10.1186/s13071-020-04010-8

35. Harnett W. Secretory products of helminth parasites as immunomodulators. Mol Biochem Parasitol. (2014) 195:130-6. doi: 10.1016/j.molbiopara.2014.03.007

36. Hewitson JP, Grainger JR, Maizels RM. Helminth immunoregulation: the role of parasite secreted proteins in modulating host immunity. Mol Biochem Parasitol. (2009) 167:1-11. doi: 10.1016/j.molbiopara.2009.04.008

37. White RR, Artavanis-Tsakonas K. How helminths use excretory secretory fractions to modulate dendritic cells. Virulence. (2012) 3:668-77. doi: 10.4161/viru.22832

38. Coakley G, McCaskill JL, Borger JG, Simbari F, Robertson E, Millar M, et al. Extracellular vesicles from a helminth parasite suppress macrophage activation and constitute an effective vaccine for protective immunity. Cell Rep. (2017) 19:1545-57. doi: 10.1016/j.celrep.2017.05.001

39. Duque-Correa MA, Schreiber F, Rodgers FH, Goulding D, Forrest S, White R, et al. Development of caecaloids to study host-pathogen interactions: new insights into immunoregulatory functions of Trichuris muris extracellular vesicles in the caecum. bioRxiv. (2020) 50:707-18. doi: 10.1101/2020.05.11.087684

40. Marcilla A, Trelis M, Cortés A, Sotillo J, Cantalapiedra F, Minguez MT, et al. Extracellular vesicles from parasitic helminths contain specific excretory/secretory proteins and are internalized in intestinal host cells. PLoS ONE. (2012) 7:e0045974. doi: 10.1371/journal.pone.0045974

41. Mekonnen GG, Pearson M, Loukas A, Sotillo J. Extracellular vesicles from parasitic helminths and their potential utility as vaccines. Expert Rev Vaccines. (2018) 17:197-205. doi: 10.1080/14760584.2018.1431125

42. McSorley HJ, Hewitson JP, Maizels RM. Immunomodulation by helminth parasites: defining mechanisms and mediators. Int $J$ Parasitol. (2013) 43:301-10. doi: 10.1016/j.ijpara.2012. 11.011

43. Baxter D. Active and passive immunity, vaccine types, excipients and licensing. Occup Med. (2007) 57:552-6. doi: 10.1093/occmed/kqm110
44. Nascimento I, Leite L. Recombinant vaccines and the development of new vaccine strategies. Braz J Med Biol Res. (2012) 45:1102-11. doi: 10.1590/S0100-879X2012007500142

45. Michel M-L, Tiollais P. Hepatitis B vaccines: protective efficacy and therapeutic potential. Pathol Biol. (2010) 58:288-95. doi: 10.1016/j.patbio.2010.01.006

46. Noon JB, Aroian RV. Recombinant subunit vaccines for soil-transmitted helminths. Parasitology. (2017) 144:1845-70. doi: 10.1017/S003118201700138X

47. Pérez O, Batista-Duharte A, González E, Zayas C, Balboa J, Cuello M, et al. Human prophylactic vaccine adjuvants and their determinant role in new vaccine formulations. Braz J Med Biol Res. (2012) 45:681-92. doi: 10.1590/S0100-879X2012007500067

48. Diemert DJ, Freire J, Valente V, Fraga CG, Talles F, Grahek S, et al. Safety and immunogenicity of the Na-GST-1 hookworm vaccine in Brazilian and American adults. PLoS Negl Trop Dis. (2017) 11:e0005574. doi: 10.1371/journal.pntd.0005574

49. Hotez PJ, Diemert D, Bacon KM, Beaumier C, Bethony JM, Bottazzi ME, et al. The human hookworm vaccine. Vaccine. (2013) 31:B227-32. doi: 10.1016/j.vaccine.2012.11.034

50. Diemert D, Campbell D, Brelsford J, Leasure C, Li G, Peng J, et al. Controlled human hookworm infection: accelerating human hookworm vaccine development. Open Forum Infect Dis. (2018) 5:ofy083. doi: 10.1093/ofid/ofy083

51. Gary EN, Weiner DB. DNA vaccines: prime time is now. Curr Opin Immunol. (2020) 65:21-7. doi: 10.1016/j.coi.2020.01.006

52. Sautto GA, Kirchenbaum GA, Diotti RA, Criscuolo E, Ferrara F. Next generation vaccines for infectious diseases. J Immunol Res. (2019) 2019:5890962. doi: 10.1155/2019/5890962

53. Ulmer JB, Wahren B, Liu MA. Gene-based vaccines: recent technical and clinical advances. Trends Mol Med. (2006) 12:216-22. doi: 10.1016/j.molmed.2006.03.007

54. Gaudinski MR, Houser KV, Morabito KM, Hu Z, Yamshchikov G, Rothwell RS, et al. Safety, tolerability, and immunogenicity of two Zika virus DNA vaccine candidates in healthy adults: randomised, open-label, phase 1 clinical trials. Lancet. (2018) 391:552-62. doi: 10.1016/S0140-6736(17)33105-7

55. Yoon I-K, Kim JH. First clinical trial of a MERS coronavirus DNA vaccine. Lancet Infect Dis. (2019) 19:924. doi: 10.1016/S1473-3099(19)30397-4

56. Lopes A, Vandermeulen G, Préat V. Cancer DNA vaccines: current preclinical and clinical developments and future perspectives. J Exp Clin Cancer Res. (2019) 38:146. doi: 10.1186/s13046-019-1154-7

57. Garren H, Robinson WH, Krasulová E, Havrdová E, Nadj C, Selmaj K, et al. Phase 2 trial of a DNA vaccine encoding myelin basic protein for multiple sclerosis. Ann Neurol. (2008) 63:611-20. doi: 10.1002/ana.21370

58. Akulova E, Murashev B, Verevochkin S, Masharsky A, Al-Shekhadat R, Poddubnyy $\mathrm{V}$, et al. The increase of the magnitude of spontaneous viral blips in some participants of phase II clinical trial of therapeutic optimized HIV DNA vaccine candidate. Vaccines. (2019) 7:92. doi: 10.3390/vaccines7030092

59. Rezaei T, Khalili S, Baradaran B, Mosafer J, Rezaei S, Mokhtarzadeh A, et al. Recent advances on HIV DNA vaccines development: Stepwise improvements to clinical trials. J Control Release. (2019) 316:116-37. doi: 10.1016/j.jconrel.2019.10.045

60. Volume. P, Roberts CC, Muthumani K, Reuschel EL, Kudchodkar SB, Zaidi FI, et al. Safety and immunogenicity of an anti-Zika virus DNA vaccinepreliminary report. N Engl J Med. (2017). doi: 10.1056/NEJMoa1708120. [Epub ahead of print].

61. Tebas P, Kraynyak KA, Patel A, Maslow JN, Morrow MP, Sylvester AJ, et al. Intradermal SynCon $®$ Ebola GP DNA vaccine is temperature stable and safely demonstrates cellular and humoral immunogenicity advantages in healthy volunteers. J Infect Dis. (2019) 220:400-10. doi: 10.1093/infdis/ jiz132

62. Wiśniewski M, Jaros S, Baska P, Cappello M, Długosz E, Wedrychowicz H. Hamsters vaccinated with Ace-mep-7 DNA vaccine produced protective immunity against Ancylostoma ceylanicum infection. Exp Parasitol. (2016) 163:1-7. doi: 10.1016/j.exppara.2016.01.006

63. Wiśniewski M, Jaros S, Baska P, Cappello M, Wedrychowicz H. Ancylostoma ceylanicum metalloprotease 6 DNA vaccination induces partial protection 
against hookworm challenge infection. Acta Parasitol. (2013) 58:376-83. doi: 10.2478/s11686-013-0151-9

64. Bejon P, Mwacharo J, Kai O, Lowe B, Todryk S, Peshu N, et al. Safety, immunogenicity and efficacy studies of candidate malaria vaccines FP9 and MVA encoding ME-TRAP in Kenyan children [MIM-PB-224908]. Acta Tropica. (2005) 95:S84.

65. Penny MA, Camponovo F, Chitnis N, Smith TA, Tanner, M. Future use-cases of vaccines in malaria control and elimination. Parasite Epidemiol Control. (2020) 2020:e00145. doi: 10.1016/j.parepi.2020.e00145

66. Kumar A, Samant M. DNA vaccine against visceral leishmaniasis: a promising approach for prevention and control. Parasite Immunol. (2016) 38:273-81. doi: 10.1111/pim.12315

67. Martínez-Rodrigo AS, Dias D, Ribeiro PA, Roatt BM, Mas A, Carrion J, et al. Immunization with the HisAK70 DNA vaccine induces resistance against leishmania amazonensis infection in BALB/c mice. Vaccines. (2019) 7:183. doi: 10.3390/vaccines 7040183

68. Frantz FG, Ito T, Cavassani KA, Hogaboam CM, Silva CL, Kunkel SL, et al. Therapeutic DNA vaccine reduces schistosoma mansoniinduced tissue damage through cytokine balance and decreased migration of myofibroblasts. Am. J Pathol. (2011) 179:223-9. doi: 10.1016/j.ajpath.2011.03.012

69. Li M-j, Lei J-h, Wang T, Lu, S-j, Guan F, Liu, W-q, et al. Cimetidine enhances the protective effect of GST DNA vaccine against Schistosoma japonicum. Exp Parasitol. (2011) 128:427-32. doi: 10.1016/j.exppara.2011.05.012

70. Běláková J, Horynová M, Krupka M, Weigl E, Raška M. DNA vaccines: are they still just a powerful tool for the future?Arch Immunol Ther Exp. (2007) 55:387. doi: 10.1007/s00005-007-0044-4

71. Radošević K, Rodriguez A, Lemckert A, Goudsmit J. Heterologous primeboost vaccinations for poverty-related diseases: advantages and future prospects. Expert Rev Vaccines. (2009) 8:577-92. doi: 10.1586/erv.09.14

72. Saade F, Petrovsky N. Technologies for enhanced efficacy of DNA vaccines. Expert Rev Vaccines. (2012) 11:189-209. doi: 10.1586/erv.11.188

73. Bambini S, Rappuoli RJD. The use of genomics in microbial vaccine development. Drug Discov Today. (2009) 14:252-60. doi: 10.1016/j.drudis.2008.12.007

74. Del Tordello E, Rappuoli R, Delany I. Chapter 3 - reverse vaccinology: exploiting genomes for vaccine design. In: Modjarrad K, Koff WC, editors. Human Vaccines. Academic Press (2017). p. 65-86. doi: 10.1016/B978-0-12-802302-0.00002-9. Available online at: http:// www.sciencedirect.com/science/article/pii/B9780128023020000029

75. Lemaire D, Barbosa T, Rihet P. Coping with genetic diversity: the contribution of pathogen and human genomics to modern vaccinology. Braz J Med. Biol Res. (2012) 45:376-85. doi: 10.1590/S0100-879X2011007500142

76. Arnon R, Ben-Yedidia T. Old and new vaccine approaches. Int Immunopharmacol. (2003) 3:1195-204. doi: 10.1016/S1567-5769(03)00016-X

77. Capecchi B, Serruto D, Adu-Bobie J, Rappuoli R, Pizza M. The genome revolution in vaccine research. Curr Issues Mol Biol. (2004) 6:17-28.

78. Moise L, Cousens L, Fueyo J, De Groot AS. Harnessing the power of genomics and immunoinformatics to produce improved vaccines. Expert Opin Drug Discov. (2011) 6:9-15. doi: 10.1517/17460441.2011.534454

79. Zawawi A, Forman R, Smith H, Mair I, Jibril M, Albaqshi MH, et al. In silico design of a T-cell epitope vaccine candidate for parasitic helminth infection. PLoS Pathog. (2020) 16:e1008243. doi: 10.1371/journal.ppat.1008243

80. Stutzer C, Richards SA, Ferreira M, Baron S, Maritz-Olivier C. Metazoan parasite vaccines: present status and future prospects. Front Cell Infect Microbiol. (2018) 8:67. doi: 10.3389/fcimb.2018.00067

81. Clark NJ, Owada K, Ruberanziza E, Ortu G, Umulisa I, Bayisenge U, et al. Parasite associations predict infection risk: incorporating co-infections in predictive models for neglected tropical diseases. Parasites Vectors. (2020) 13:1-16. doi: 10.1186/s13071-020-04016-2

82. Howarth M, Brune KD. New routes and opportunities for modular construction of particulate vaccines: stick, click and glue. Front Immunol. (2018) 9:1432. doi: 10.3389/fimmu.2018.01432

83. Knox DP, Redmond DL, Skuce PJ, Newlands GF. The contribution of molecular biology to the development of vaccines against nematode and trematode parasites of domestic ruminants. Vet Parasitol. (2001) 101:311-35. doi: 10.1016/S0304-4017(01)00558-1
84. Diemert DJ, Bottazzi ME, Plieskatt J, Hotez PJ, Bethony JM. Lessons along the critical path: developing vaccines against human helminths. Trends Parasitol. (2018) 34:747-58. doi: 10.1016/j.pt.2018.07.005

85. Dixon H, Little MC, Else KJ. Characterisation of the protective immune response following subcutaneous vaccination of susceptible mice against Trichuris muris. Int. J Parasitol. (2010) 40:683-93. doi: 10.1016/j.ijpara.2009.11.008

86. Girod N, Brown A, Pritchard D, Billett E. Successful vaccination of BALB/c mice against human hookworm (Necator americanus): the immunological phenotype of the protective response. Int J Parasitol. (2003) 33:71-80. doi: $10.1016 / \mathrm{S} 0020-7519(02) 00248-5$

87. Urban JJ, Romanowski R. Ascaris suum: protective immunity in pigs immunized with products from eggs and larvae. Exp Parasitol. (1985) 60:245-54. doi: 10.1016/0014-4894(85)90028-1

88. Geldhof P, de Maere V, Vercruysse J, and Claerebout, E. Recombinant expression systems: the obstacle to helminth vaccines? Trends Parasitol. (2007) 23:527-32. doi: 10.1016/j.pt.2007.08.012

89. Hewitson JP, Maizels RM. Vaccination against helminth parasite infections. Expert Rev Vaccines. (2014) 13:473-87. doi: 10.1586/14760584.2014.893195

90. Morrison WI, Tomley F. Development of vaccines for parasitic diseases of animals: challenges and opportunities. Parasite Immunol. (2016) 38:707-8. doi: $10.1111 /$ pim. 12398

91. Briggs N, Wei J, Versteeg L, Zhan B, Keegan B, Damania A, et al. Trichuris muris whey acidic protein induces type 2 protective immunity against whipworm. PLoS Pathog. (2018) 14:e1007273. doi: 10.1371/journal.ppat.1007273

92. Patronov A, Doytchinova I. T-cell epitope vaccine design by immunoinformatics. Open Biol. (2013) 3:120139. doi: 10.1098/rsob.120139

93. Bartlett S, Skwarczynski M, Xie X, Toth I, Loukas A, Eichenberger RM. Development of natural and unnatural amino acid delivery systems against hookworm infection. Precision Nanomed. (2020) 3:471-82. doi: 10.33218/prnano3(1).191210.1

94. Carter D, Reed SG. Role of adjuvants in modeling the immune response. Curr Opin HIV AIDS. (2010) 5:409. doi: 10.1097/COH.0b013e32833d2cdb

95. Dorrington MG, Bowdish DM. Immunosenescence and novel vaccination strategies for the elderly. Front Immunol. (2013) 4:171. doi: 10.3389/fimmu.2013.00171

96. Khurana S, Chearwae W, Castellino F, Manischewitz J, King LR, Honorkiewicz A, et al. Vaccines with MF59 adjuvant expand the antibody repertoire to target protective sites of pandemic avian $\mathrm{H} 5 \mathrm{~N} 1$ influenza virus. Sci Transl Med. (2010) 2:15ra5. doi: 10.1126/scitranslmed. 3000624

97. Dietrich J, Andreasen LV, Andersen P, and Agger EM. Inducing dose sparing with inactivated polio virus formulated in adjuvant CAF01. PLOS ONE. (2014) 9:e0100879. doi: 10.1371/journal.pone. 0100879

98. Copland MJ, Rades T, Davies NM, Baird MA. Lipid based particulate formulations for the delivery of antigen. Immunol Cell Biol. (2005) 83:97105. doi: 10.1111/j.1440-1711.2005.01315.x

99. Schijns V, O'Hagan D. Immunopotentiators in Modern Vaccines. Academic Press; Elsevier (2016).

100. Cimica V, Galarza JM. Adjuvant formulations for virus-like particle (VLP) based vaccines. Clin Immunol. (2017) 183:99-108. doi: 10.1016/j.clim.2017.08.004

101. McKee AS, Marrack P. Old and new adjuvants. Curr Opin Immunol. (2017) 47:44-51. doi: 10.1016/j.coi.2017.06.005

102. Stils HF Jr. Adjuvants and antibody production: dispelling the myths associated with Freund's complete and other adjuvants. ILAR J. (2005) 46:280-93. doi: 10.1093/ilar.46.3.280

103. Lindblad EB. Freund's Adjuvants. Vaccine Adjuvants. Totowa, NJ: Springer (2000). p. 49-63. doi: 10.1385/1-59259-083-7:49

104. Marrack P, McKee AS, Munks MW. Towards an understanding of the adjuvant action of aluminium. Nat Rev Immunol. (2009) 9:287. doi: $10.1038 /$ nri2510

105. Knudsen NPH, Olsen A, Buonsanti C, Follmann F, Zhang Y, Coler RN, et al. Different human vaccine adjuvants promote distinct antigen-independent immunological signatures tailored to different pathogens. Sci Rep. (2016) 6:19570. doi: 10.1038/srep19570 
106. Klippstein R, Pozo D. Nanotechnology-based manipulation of dendritic cells for enhanced immunotherapy strategies. Nanomed Nanotechnol Biol Med. (2010) 6:523-9. doi: 10.1016/j.nano.2010.01.001

107. Skwarczynski M, Toth I. Micro-and Nanotechnology in Vaccine Development. New York, NY: William Andrew (2016).

108. Singh M, Chakrapani A, O'Hagan D. Nanoparticles and microparticles as vaccine-delivery systems. Expert Rev Vaccines. (2007) 6:797-808. doi: 10.1586/14760584.6.5.797

109. Gamvrellis A, Leong D, Hanley JC, Xiang SD, Mottram P, Plebanski M. Vaccines that facilitate antigen entry into dendritic cells. Immunol Cell Biol. (2004) 82:506-16. doi: 10.1111/j.0818-9641.2004.01271.x

110. Gomes AC, Flace A, Saudan P, Zabel F, Cabral-Miranda G, Turabi AE, et al. adjusted Particle size eliminates the need of linkage of antigen and adjuvants for appropriated $\mathrm{T}$ cell responses in virus-like particle-based vaccines. Front Immunol. (2017) 8:226. doi: 10.3389/fimmu.2017.00226

111. Choi B, Kim H, Choi H, Kang S. Protein Cage Nanoparticles as Delivery Nanoplatforms. Biomimetic Medical Materials. Singapore: Springer (2018). p. 27-43.

112. Zeltins A. Construction and characterization of virus-like particles: a review. Mol Biotechnol. (2013) 53:92-107. doi: 10.1007/s12033-012-9598-4

113. Fogarty JA, Swartz JR. The exciting potential of modular nanoparticles for rapid development of highly effective vaccines. Curr Opin Chem Eng. (2018) 19:1-8. doi: 10.1016/j.coche.2017.11.001

114. Hawkes N. European medicines agency approves first malaria vaccine. $B M J$. (2015) 351:h4067. doi: 10.1136/bmj.h4067

115. Pance A. How elusive can a malaria vaccine be? Nat RevMicrobiol. (2019) 17:129. doi: 10.1038/s41579-018-0148-3

116. Guo J, Zhou A, Sun X, Sha W, Ai K, Pan G, et al. Immunogenicity of a viruslike-particle vaccine containing multiple antigenic epitopes of Toxoplasma gondii against acute and chronic toxoplasmosis in mice. Front Immunol. (2019) 10:592. doi: 10.3389/fimmu.2019.00592

117. Lee S-H, Kim S-S, Lee D-H, Kim A-R, Quan F-S. Evaluation of protective efficacy induced by virus-like particles containing a Trichinella spiralis excretory-secretory (ES) protein in mice. Parasit Vectors. (2016) 9:384. doi: 10.1186/s13071-016-1662-7

118. Lee D-H, Kim A-R, Lee S-H, Quan F-S. Virus-like particles vaccine containing Clonorchis sinensis tegumental protein induces partial protection against Clonorchis sinensis infection. Parasit Vectors. (2017) 10:626. doi: 10.1186/s13071-017-2526-5

119. Cauwelaert ND, Desbien AL, Hudson TE, Pine SO, Reed SG, Coler RN, et al. The TLR4 agonist vaccine adjuvant, GLA-SE, requires canonical and atypical mechanisms of action for TH1 induction. PLoS ONE. (2016) 11:0146372. doi: 10.1371/journal.pone.0146372

120. Thompson BS, Chilton PM, Ward JR, Evans JT, Mitchell TC. The lowtoxicity versions of LPS, MPL $\AA$ adjuvant and RC529, are efficient adjuvants for CD4+ T cells. J Leukoc Biol. (2005) 78:1273-80. doi: 10.1189/jlb. 0305172

121. Vitoriano-Souza J, Mathias FAS, das Dores Moreira N, de Oliveira AguiarSoares RD, de Abreu Vieira PM, Teixeira-Carvalho A, et al. Effect on cellular recruitment and the innate immune response by combining saponin, monophosphoryl lipid-A and Incomplete Freund's Adjuvant with Leishmania (Viannia) braziliensis antigens for a vaccine formulation. Vaccine. (2019) 37:7269-79. doi: 10.1016/j.vaccine.2019.09.067

122. Wang X, Dong L, Ni H, Zhou S, Xu Z, Hoellwarth JS, et al. Combined TLR7/8 and TLR9 ligands potentiate the activity of a Schistosoma japonicum DNA vaccine. PLoS Negl Trop Dis. (2013) 7:e2164. doi: 10.1371/journal.pntd.0002164

123. Coler RN, Day TA, Ellis R, Piazza FM, Beckmann AM, Vergara J, et al. The TLR-4 agonist adjuvant, GLA-SE, improves magnitude and quality of immune responses elicited by the ID 93 tuberculosis vaccine: first-in-human trial. NPJ Vaccines. (2018) 3:34. doi: 10.1038/s41541-0180057-5

124. Ko E-J, Lee Y-T, Kim K-H, Lee Y, Jung Y-J, Kim M-C, et al. Roles of aluminum hydroxide and monophosphoryl lipid A adjuvants in overcoming CD4+ $\mathrm{T}$ cell deficiency to induce isotype-switched IgG antibody responses and protection by T-dependent influenza vaccine. J Immunol. (2017) 198:279-91. doi: 10.4049/jimmunol.1600173
125. McCluskie M, Krieg A. Enhancement of infectious disease vaccines through TLR9-dependent recognition of CpG DNA. In: Pulendran B, Ahmed $\mathrm{R}$, editors From Innate Immunity to Immunological Memory. Berlin; Heidelberg, ON: Springer (2006). p. 155-78.

126. Vollmer J, Krieg AM. Immunotherapeutic applications of $\mathrm{CpG}$ oligodeoxynucleotide TLR9 agonists. Adv Drug Deliv Rev. (2009) 61:195-204. doi: 10.1016/j.addr.2008.12.008

127. Kasturi SP, Skountzou I, Albrecht RA, Koutsonanos D, Hua T, Nakaya HI, et al. Programming the magnitude and persistence of antibody responses with innate immunity. Nature. (2011) 470:543-7. doi: 10.1038/nature09737

128. Rostami H, Ebtekar M, Ardestani MS, Yazdi MH, Mahdavi M. Coutilization of a TLR5 agonist and nano-formulation of HIV-1 vaccine candidate leads to increased vaccine immunogenicity and decreased immunogenic dose: a preliminary study. Immunol Lett. (2017) 187:19-26. doi: 10.1016/j.imlet.2017.05.002

129. Thompson EA, Ols S, Miura K, Rausch K, Narum DL, Spångberg M, et al. TLR-adjuvanted nanoparticle vaccines differentially influence the quality and longevity of responses to malaria antigen Pfs25. JCI Insight. (2018) 3:120692. doi: $10.1172 /$ jci.insight. 120692

130. Hotez PJ. The global fight to develop antipoverty vaccines in the anti-vaccine era. Hum Vaccines Immunother. (2018) 14:2128-31. doi: 10.1080/21645515.2018.1430542

131. Cunningham AL, Garçon N, Leo O, Friedland LR, Strugnell R, Laupèze B, et al. Vaccine development: from concept to early clinical testing. Vaccine. (2016) 34:6655-64. doi: 10.1016/j.vaccine.2016.10.016

132. Grencis RK. Immunity to helminths: resistance, regulation, and susceptibility to gastrointestinal nematodes. Annu Rev Immunol. (2015) 33:201-25. doi: 10.1146/annurev-immunol-032713-120218

133. Hurst RJ, Else KJ. Trichuris muris research revisited: a journey through time. Parasitology. (2013) 140:1325-39. doi: 10.1017/S0031182013001054

134. Faulkner H, Turner J, Kamgno J, Pion SD, Boussinesq M, Bradley JE. Ageand infection intensity-dependent cytokine and antibody production in human trichuriasis: the importance of IgE. J Infect Dis. (2002) 185:665-74. doi: $10.1086 / 339005$

135. Jackson JA, Turner JD, Rentoul L, Faulkner H, Behnke JM, Hoyle M, et al. T helper cell type 2 responsiveness predicts future susceptibility to gastrointestinal nematodes in humans. J Infect Dis. (2004) 190:1804-11. doi: $10.1086 / 425014$

136. Turner J, Faulkner H, Kamgno J, Else K, Boussinesq M, Bradley JE. A comparison of cellular and humoral immune responses to trichuroid derived antigens in human trichuriasis. Parasite Immunol. (2002) 24:83-93. doi: $10.1046 / j .0141-9838.2001 .00442 . x$

137. Pit D, Polderman A, Schulz-Key H, Soboslay P. Prenatal immune priming with helminth infections: parasite-specific cellular reactivity and Th1 and Th2 cytokine responses in neonates. Allergy. (2000) 55:732-9. doi: 10.1034/j.1398-9995.2000.00477.x

138. Quinnell RJ, Pritchard DI, Raiko A, Brown AP, Shaw M-A. Immune responses in human necatoriasis: association between interleukin-5 responses and resistance to reinfection. J Infect Dis. (2004) 190:430-8. doi: $10.1086 / 422256$

139. Cooper PJ, Chico ME, Sandoval C, Espinel I, Guevara A, Kennedy MW, et al. Human infection with Ascaris lumbricoides is associated with a polarized cytokine response. J Infect Dis. (2000) 182:1207-13. doi: 10.1086/315830

140. Palmer D, Hall A, Haque R, Anwar K. Antibody isotype responses to antigens of Ascaris lumbricoides in a case-control study of persistently heavily infected Bangladeshi children. Parasitology. (1995) 111:385-93. doi: $10.1017 /$ S0031182000081944

141. Zakzuk J, Acevedo N, Harb H, Eick L, Renz H, Potaczek DP, et al. IgE levels to Ascaris and house dust mite allergens are associated with increased histone acetylation at key type-2 immune genes. Front Immunol. (2020) 11:756. doi: $10.3389 /$ fimmu.2020.00756

142. Turner JD, Faulkner H, Kamgno J, Cormont F, van Snick J, Else KJ, et al. Th2 cytokines are associated with reduced worm burdens in a human intestinal helminth infection. J Infect Dis. (2003) 188:1768-75. doi: 10.1086/ 379370

143. Huang L, Appleton JA. Eosinophils in helminth infection: defenders and dupes. Trends Parasitol. (2016) 32:798-807. doi: 10.1016/j.pt.2016.05.004 
144. Loukas A, Prociv P. Immune responses in hookworm infections. Clin Microbiol Rev. (2001) 14:689-703. doi: 10.1128/CMR.14.4.689-703.2001

145. Meeusen ENT, Balic A. Do eosinophils have a role in the killing of helminth parasites? Parasitol Today. (2000) 16:95-101. doi: 10.1016/S0169-4758(99)01607-5

146. Dixon H, Blanchard C, Deschoolmeester ML, Yuill NC, Christie JW, Rothenberg ME, et al. The role of Th2 cytokines, chemokines and parasite products in eosinophil recruitment to the gastrointestinal mucosa during helminth infection. Eur J Immunol. (2006) 36:1753-63. doi: 10.1002/eji.200535492

147. Teixeira M, Cara D, Correa DN. Mechanisms underlying eosinophil trafficking and their relevance in vivo. Histol Histopathol. (2000) 15:899-920. doi: 10.14670/HH-15.899

148. Capron M, Capron A. Effector functions of eosinophils in schistosomiasis. Mem Inst Oswaldo Cruz. (1992) 87:167-70. doi: 10.1590/S0074-02761992000800025

149. Capron M, Torpier G, Capron A. In vitro killing of S. mansoni schistosomula by eosinophils from infected rats: role of cytophilic antibodies. J Immunol. (1979) 123:2220-30.

150. Venturiello S, Giambartolomei G, Costantino S. Immune cytotoxic activity of human eosinophils against Trichinella spiralis newborn larvae. Parasite Immunol. (1995) 17:555-9. doi: 10.1111/j.1365-3024.1995.tb00998.x

151. Coakley G, Volpe B, Bouchery T, Shah K, Butler A, Geldhof P, et al. Immune serum-activated human macrophages coordinate with eosinophils to immobilize Ascaris suum larvae. Parasite Immunol. (2020) 42:e12728. doi: $10.1111 /$ pim. 12728

152. Cliffe LJ, Grencis RK. The Trichuris muris system: a paradigm of resistance and susceptibility to intestinal nematode infection. Adv Parasitol. (2004) 57:255-307. doi: 10.1016/S0065-308X(04)57004-5

153. Cliffe LJ, Humphreys NE, Lane TE, Potten CS, Booth C, Grencis RK. Accelerated intestinal epithelial cell turnover: a new mechanism of parasite expulsion. Science. (2005) 308:1463-5. doi: 10.1126/science.1108661

154. Khan W, Richard M, Akiho H, Blennerhasset P, Humphreys N, Grencis $\mathrm{R}$, et al. Modulation of intestinal muscle contraction by interleukin9 (IL-9) or IL-9 neutralization: correlation with worm expulsion in murine nematode infections. Infect Immun. (2003) 71:2430-8. doi: 10.1128/IAI.71.5.2430-2438.2003

155. Artis D, Wang ML, Keilbaugh SA, He W, Brenes M, Swain GP, et al. RELM $\beta / F I Z Z 2$ is a goblet cell-specific immune-effector molecule in the gastrointestinal tract. Proc Natl Acad Sci USA. (2004) 101:13596-600. doi: 10.1073/pnas.0404034101

156. Bancroft AJ, Artis D, Donaldson DD, Sypek JP, Grencis RK. Gastrointestinal nematode expulsion in IL-4 knockout mice is IL13 dependent. Eur J Immunol. (2000) 30:2083-91. doi: 10.1002/15214141(200007)30:7<2083::AID-IMMU2083>3.0.CO;2-3

157. Bancroft AJ, McKenzie AN, Grencis RK. A critical role for IL-13 in resistance to intestinal nematode infection. J Immunol. (1998) 160:3453-61.

158. Hasnain S, Thornton D, Grencis R. Changes in the mucosal barrier during acute and chronic Trichuris muris infection. Parasite Immunol. (2011) 33:4555. doi: 10.1111/j.1365-3024.2010.01258.x

159. Hasnain SZ, Wang H, Ghia JE, Haq N, Deng Y, Velcich A, et al. Mucin gene deficiency in mice impairs host resistance to an enteric parasitic infection. Gastroenterology. (2010) 138:63-1771. e5. doi: 10.1053/j.gastro.2010.01.045

160. Richard M, Grencis RK, Humphreys NE, Renauld J-C, Van Snick J. Anti-IL-9 vaccination prevents worm expulsion and blood eosinophilia in Trichuris muris-infected mice. Proc Natl Acad Sci USA. (2000) 97:767-72. doi: 10.1073/pnas.97.2.767

161. Li J, Chen S, Xiao X, Zhao Y, Ding W, Li XC. IL-9 and Th9 cells in health and diseases-from tolerance to immunopathology. Cytokine Growth Factor Rev. (2017) 37:47-55. doi: 10.1016/j.cytogfr.2017.07.004

162. Deslyper G, Colgan TJ, Cooper AJ, Holland CV, Carolan JC. A proteomic investigation of hepatic resistance to Ascaris in a murine model. PLoS Negl Trop Dis. (2016) 10:e0004837. doi: 10.1371/journal.pntd. 0004837

163. Gazzinelli-Guimarães PH, Gazzinelli-Guimarães AC, Silva FN, Mati VLT, de Carvalho Dhom-Lemos L, Barbosa FS, et al. Parasitological and immunological aspects of early Ascaris s infection in mice. Int J Parasitol. (2013) 43:697-706. doi: 10.1016/j.ijpara.2013.02.009
164. Weatherhead JE, Porter P, Coffey A, Haydel D, Versteeg L, Zhan B, et al. Ascaris larval infection and lung invasion directly induce severe allergic airway disease in mice. Infect Immun. (2018) 86:e00533-18. doi: 10.1128/IAI.00533-18

165. Masure D, Wang T, Vlaminck J, Claerhoudt S, Chiers K, van den Broeck W, et al. The intestinal expulsion of the roundworm Ascaris suum is associated with eosinophils, intra-epithelial $\mathrm{T}$ cells and decreased intestinal transit time. PLoS Negl Trop Dis. (2013) 7:e0002588. doi: 10.1371/journal.pntd. 0002588

166. Harris N, Gause WC. To B or not to B: B cells and the Th2type immune response to helminths. Trends Immunol. (2011) 32:80-8. doi: $10.1016 /$ j.it.2010.11.005

167. Liu Q, Kreider T, Bowdridge S, Liu Z, Song Y, Gaydo AG, et al. B cells have distinct roles in host protection against different nematode parasites. J Immunol. (2010) 184:5213-23. doi: 10.4049/jimmunol.0902879

168. Sahputra R, Else KJ, Rückerl D, Couper K, Müller W. The essential role played by B cells in supporting protective immunity against Trichuris muris infection is by controlling the Th1/Th2 balance in the mesenteric lymph nodes and depends on host genetic background. Front Immunol. (2019) 10:2842. doi: 10.3389/fimmu.2019.02842

169. Blackwell NM, Else KJ. B cells and antibodies are required for resistance to the parasitic gastrointestinal nematode Trichuris muris. Infect Immun. (2001) 69:3860-8. doi: 10.1128/IAI.69.6.3860-3868.2001

170. Else KJ, Grencis RK. Antibody-independent effector mechanisms in resistance to the intestinal nematode parasite Trichuris muris. Infect Immun. (1996) 64:2950-4. doi: 10.1128/IAI.64.8.2950-2954.1996

171. Harris N, Pleass R, Behnke J. Understanding the role of antibodies in murine infections with Heligmosomoides (polygyrus) bakeri: 35 years ago, now and 35 years ahead. Parasite Immunol. (2014) 36:115-24. doi: 10.1111/pim. 12057

172. Pleass RJ, Behnke JM. B-cells get the T-cells but antibodies get the worms. Trends Parasitol. (2009) 25:443-6. doi: 10.1016/j.pt.2009.07.001

173. Esser-von Bieren J, Mosconi I, Guiet R, Piersgilli A, Volpe B, Chen F, et al. Antibodies trap tissue migrating helminth larvae and prevent tissue damage by driving IL- $4 \mathrm{R} \alpha$-independent alternative differentiation of macrophages. PLoS Pathog. (2013) 9:e1003771. doi: 10.1371/journal.ppat.1003771

174. de Ruiter K, Jochems SP, Tahapary DL, Stam KA, König M, van Unen V, et al. Helminth infections drive heterogeneity in human type 2 and regulatory cells. Sci Transl Med. (2020) 12:eaaw3703. doi: 10.1126/scitranslmed.aaw3703

175. Haichou X, Yan W, Shuhua X, Sen L, Yong W, Guangjin S, et al. Epidemiology of human ancylostomiasis among rural villagers in Nanlin County (Zhongzhou Village), Anhui Province, China: II. Seroepidemiological studies of the age relationships of serum antibody levels and infection status. Southeast Asian J Trop Med Public Health. (2000) 31:736-41.

176. Hagel I, Lynch N, Di Prisco M, Rojas E, Perez M, Alvarez N. Ascaris reinfection of slum children: relation with the IgE response. Clin Exp Immunol. (1993) 94:80-3. doi: 10.1111/j.1365-2249.1993.tb05981.x

177. King EM, Kim H, Dang N, Michael E, Drake L, Needham C, et al. Immuno-epidemiology of Ascaris lumbricoides infection in a high transmission community: antibody responses and their impact on current and future infection intensity. Parasite Immunol. (2005) 27:89-96. doi: 10.1111/j.1365-3024.2005.00753.x

178. Brooker S, Bethony J, Hotez PJ. Human hookworm infection in the 21st century. Adv Parasitol. (2004) 58:197. doi: 10.1016/S0065-308X(04)58004-1

179. Bungiro R Jr, Sun T, Harrison L, Shoemaker C, Cappello M. Mucosal antibody responses in experimental hookworm infection. Parasite Immunol. (2008) 30:293-303. doi: 10.1111/j.1365-3024.2008.01023.x

180. Kumar N, Gupta P, Saha K, Misra R, Agarwal D, Chuttani H. Serum and intestinal immunoglobulins in patients of ancylostomiasis. Indian J Med Res. (1980) 71:531-7.

181. Pritchard D, Walsh E, Quinell R, RAIKO A, Edmonds P, Keymer A. Isotypic variation in antibody responses in a community in Papua New Guinea to larval and adult antigens during infection, and following reinfection, with the hookworm Necator americanus. Parasite Immunol. (1992) 14:617-31. doi: 10.1111/j.1365-3024.1992. tb00034.x 
182. Broadhurst MJ, Leung JM, Kashyap V, McCune JM, Mahadevan U, McKerrow JH. IL-22 + CD4+ T cells are associated with therapeutic trichuris trichiura infection in an ulcerative colitis patient. Sci Transl Med. (2010) 2:60ra88. doi: 10.1126/scitranslmed.3001500

183. Smallwood TB, Giacomin PR, Loukas A, Mulvenna JP, Clark RJ, Miles JJ. Helminth immunomodulation in autoimmune disease. Front Immunol. (2017) 8:453. doi: 10.3389/fimmu.2017.00453

184. Ricci ND, Fiúza JA, Bueno LL, Cançado GG, Gazzinelli-Guimarães $\mathrm{PH}$, Martins VG, et al. Induction of CD4(+)CD25(+)FOXP3(+) regulatory $\mathrm{T}$ cells during human hookworm infection modulates antigenmediated lymphocyte proliferation. PLoS Negl Trop Dis. (2011) 5:e1383. doi: 10.1371/journal.pntd.0001383

185. Schopf LR, Hoffmann KF, Cheever AW, Urban JF, Wynn TA. IL-10 is critical for host resistance and survival during gastrointestinal helminth infection. $J$ Immunol. (2002) 168:2383-92. doi: 10.4049/jimmunol.168.5.2383

186. D'Elia R, Behnke JM, Bradley JE, Else KJ. Regulatory T cells: a role in the control of helminth-driven intestinal pathology and worm survival. $J$ Immunol. (2009) 182:2340-8. doi: 10.4049/jimmunol.0802767

187. Ferreira I, Smyth D, Gaze S, Aziz A, Giacomin P, Ruyssers N, et al. Hookworm excretory/secretory products induce interleukin-4 (IL-4)+ IL$10+\mathrm{CD} 4+\mathrm{T}$ cell responses and suppress pathology in a mouse model of colitis. Infect Immun. (2013) 81:2104-11. doi: 10.1128/IAI.00563-12

188. Elliott DE, Weinstock JV. Helminthic Therapy: Using Worms to Treat Immune-Mediated Disease. In: Fallon PG, editor. Pathogen-Derived Immunomodulatory Molecules. New York, NY: Springer (2009). p. 157-66.

189. McKay DM. The therapeutic helminth? Trends Parasitol. (2009) 25:109-14. doi: $10.1016 /$ j.pt.2008.11.008

190. Sugimoto K, Ogawa A, Mizoguchi E, Shimomura Y, Andoh A, Bhan AK, et al. IL-22 ameliorates intestinal inflammation in a mouse model of ulcerative colitis. J Clin Invest. (2008) 118:534-44. doi: 10.1172/JCI33194

191. Yazdanbakhsh M, van den Biggelaar A, Maizels RM. Th2 responses without atopy: immunoregulation in chronic helminth infections and reduced allergic disease. Trends Immunol. (2001) 22:372-7. doi: 10.1016/S1471-4906(01)01958-5

192. Salgame P, Yap GS, Gause WC. Effect of helminth-induced immunity on infections with microbial pathogens. Nat Immunol. (2013) 14:1118. doi: $10.1038 /$ ni. 2736

193. Kastenmüller W, Kastenmüller K, Kurts C, Seder RA. Dendritic celltargeted vaccines-hope or hype? Nat Rev Immunol. (2014) 14:705-11. doi: $10.1038 /$ nri3727

194. Hsia Y, Bale JB, Gonen S, Shi D, Sheffler W, Fong KK, et al. Design of a hyperstable 60-subunit protein icosahedron. Nature. (2016) 535:136-9. doi: $10.1038 /$ nature 18010

195. Lai Y-T, Reading E, Hura GL, Tsai K-L, Laganowsky A, Asturias FJ, et al. Structure of a designed protein cage that self-assembles into a highly porous cube. Nat Chem. (2014) 6:1065. doi: 10.1038/nchem.2107

196. Visciano ML, Tagliamonte M, Tornesello ML, Buonaguro FM, Buonaguro L. Effects of adjuvants on IgG subclasses elicited by virus-like particles. J Transl Med. (2012) 10:4. doi: 10.1186/1479-5876-10-4

197. Macri C, Dumont C, Panozza S, Lahoud MH, Caminschi I, Villadangos JA, et al. Antibody-mediated targeting of antigen to C-type lectin-like receptors Clec9A and Clec12A elicits different vaccination outcomes. Mol Immunol. (2017) 81:143-50. doi: 10.1016/j.molimm.2016.12.010

198. Lahoud MH, Ahmet F, Kitsoulis S, Wan SS, Vremec D, Lee CN, et al. Targeting antigen to mouse dendritic cells via Clec9A induces potent CD4 T cell responses biased toward a follicular helper phenotype. J Immunol. (2011) 187:842-50. doi: 10.4049/jimmunol.1101176

199. Hong S, Zhang Z, Liu H, Tian M, Zhu X, Zhang Z, et al. B cells are the dominant antigen-presenting cells that activate naive $\mathrm{CD} 4+\mathrm{T}$ cells upon immunization with a virus-derived nanoparticle antigen. Immunity. (2018) 49:695-708. e4. doi: 10.1016/j.immuni.2018.08.012

200. Miller T. Effect of X-irradiation upon the infective larvae of Ancylostoma caninum and the immunogenic effect in dogs of a single infection with 40 kr-irradiated larvae. J Parasitol. (1964) 50:735-42. doi: 10.2307/3276194

201. Miller T. Effect of route of administration of vaccine and challenge on the immunogenic efficiency of double vaccination with irradiated Ancylostoma caninum larvae. J Parasitol. (1965) 51:200-6. doi: 10.2307/3276081
202. Schneider B, Jariwala AR, Periago MV, Gazzinelli MF, Bose SN, Hotez PJ, et al. A history of hookworm vaccine development. Hum Vaccine. (2011) 7:1234-44. doi: 10.4161/hv.7.11.18443

203. Bottazzi M. The human hookworm vaccine: recent updates and prospects for success. J Helminthol. (2015) 89:540-4. doi: 10.1017/S0022149X15000206

204. Bethony J, Loukas A, Smout M, Brooker S, Mendez S, Plieskatt J, et al. Antibodies against a secreted protein from hookworm larvae reduce the intensity of hookworm infection in humans and vaccinated laboratory animals. FASEB J. (2005) 19:1743-5. doi: 10.1096/fj.05-3936fje

205. Hotez PJ, Ashcom J, Zhan B, Bethony J, Loukas A, Hawdon J, et al. Effect of vaccination with a recombinant fusion protein encoding an astacinlike metalloprotease (MTP-1) secreted by host-stimulated Ancylostoma caninum third-stage infective larvae. J Parasitol. (2003) 89:8535. doi: 10.1645/GE-46R

206. Mendez S, Zhan B, Goud G, Ghosh K, Dobardzic A, Wu W, et al. Effect of combining the larval antigens Ancylostoma secreted protein 2 (ASP-2) and metalloprotease 1 (MTP-1) in protecting hamsters against hookworm infection and disease caused by Ancylostoma ceylanicum. Vaccine. (2005) 23:3123-30. doi: 10.1016/j.vaccine.2004.12.022

207. Williamson AL, Lustigman S, Oksov Y, Deumic V, Plieskatt J, Mendez S, et al. Ancylostoma caninum MTP-1, an astacin-like metalloprotease secreted by infective hookworm larvae, is involved in tissue migration. Infect Immun. (2006) 74:961-7. doi: 10.1128/IAI.74.2.961-967.2006

208. Zhan B, Hotez PJ, Wang Y, Hawdon JM. A developmentally regulated metalloprotease secreted by host-stimulated Ancylostoma caninum thirdstage infective larvae is a member of the astacin family of proteases. Mol Biochem Parasitol. (2002) 2:291-6. doi: 10.1016/S0166-6851(01)00453-4

209. Fujiwara RT, Zhan B, Mendez S, Loukas A, Bueno LL, Wang Y, et al. Reduction of worm fecundity and canine host blood loss mediates protection against hookworm infection elicited by vaccination with recombinant Ac-16. Clin Vaccine Immunol. (2007) 14:281-7. doi: 10.1128/CVI.00404-06

210. Diemert DJ, Pinto AG, Freire J, Jariwala A, Santiago H, Hamilton RG, et al. Generalized urticaria induced by the Na-ASP-2 hookworm vaccine: implications for the development of vaccines against helminths. J Allergy Clin Immunol. (2012) 130:169-76. e6. doi: 10.1016/j.jaci.2012.04.027

211. Goud GN, Zhan B, Ghosh K, Loukas A, Hawdon J, Dobardzic A, et al. Cloning, yeast expression, isolation, and vaccine testing of recombinant Ancylostoma-secreted protein (ASP)-1 and ASP-2 from Ancylostoma ceylanicum. J Infect Dis. (2004) 189:919-29. doi: 10.1086/381901

212. Zhan B, Santiago H, Keegan B, Gillespie P, Xue J, Bethony J, et al. Fusion of Na-ASP-2 with human immunoglobulin Fcy abrogates histamine release from basophils sensitized with anti-Na-ASP-2 IgE. Parasite Immunol. (2012) 34:404-11. doi: 10.1111/j.1365-3024.2012.01371.x

213. Bethony J, Brooker S, Albonico M, Geiger SM, Loukas A, Diemert D, et al. Soil-transmitted helminth infections: ascariasis, trichuriasis, and hookworm. Lancet. (2006) 367:1521-32. doi: 10.1016/S0140-6736(06)68653-4

214. Bethony JM, Simon G, Diemert DJ, Parenti D, Desrosiers A, Schuck S, et al. Randomized, placebo-controlled, double-blind trial of the Na-ASP2 hookworm vaccine in unexposed adults. Vaccine. (2008) 26:2408-17. doi: 10.1016/j.vaccine.2008.02.049

215. Fujiwara RT, Bethony J, Bueno LL, Wang Y, Ahn SY, Samuel A, et al. Immunogenicity of the hookworm Na-ASP-2 vaccine candidate: characterization of humoral and cellular responses after vaccination in the Sprague Dawley rat. Hum Vaccines. (2005) 1:123-8. doi: 10.4161/hv.1. 3.1924

216. Mendez S, D'samuel A, Antoine A, Ahn S, Hotez P. Use of the air pouch model to investigate immune responses to a hookworm vaccine containing the Na-ASP-2 protein in rats. Parasite Immunol. (2008) 30:53-6. doi: 10.1111/j.1365-3024.2007.00994.x

217. Chapman MD, Pomés A, Breiteneder H, Ferreira F. Nomenclature and structural biology of allergens. J Allergy Clin Immunol. (2007) 119:414-20. doi: 10.1016/j.jaci.2006.11.001

218. Traidl-Hoffmann C, Jakob T, Behrendt H. Determinants of allergenicity. J Allergy Clin Immunol. (2009) 123:558-66. doi: 10.1016/j.jaci.2008.12.003

219. Dimitrov I, Flower DR, Doytchinova I. AllerTOP-a server for in silico prediction of allergens. BMC Bioinform. (2013) 14:S4. doi: 10.1186/1471-2105-14-S6-S4 
220. Baska P, Wiśniewski M, Krzyzowska M, Długosz E, Zygner W, Górski P, et al. Molecular cloning and characterisation of in vitro immune response against astacin-like metalloprotease Ace-MTP-2 from Ancylostoma ceylanicum. Exp Parasitol. (2013) 133:472-82. doi: 10.1016/j.exppara.2013.01.006

221. Ranjit N, Zhan B, Hamilton B, Stenzel D, Lowther J, Pearson M, et al. Proteolytic degradation of hemoglobin in the intestine of the human hookworm Necator americanus. J Infect Dis. (2009) 199:904-12. doi: $10.1086 / 597048$

222. Loukas A, Bethony JM, Mendez S, Fujiwara RT, Goud GN, Ranjit N, et al. Vaccination with recombinant aspartic hemoglobinase reduces parasite load and blood loss after hookworm infection in dogs. PLoS Med. (2005) 2:e0020295. doi: 10.1371/journal.pmed.0020295

223. Curti E, Seid CA, Hudspeth E, Center L, Rezende W, Pollet J, et al. Optimization and revision of the production process of the Necator americanus glutathione S-transferase 1 (Na-GST-1), the lead hookworm vaccine recombinant protein candidate. Hum Vaccines Immunother. (2014) 10:1914-25. doi: 10.4161/hv.28872

224. Pearson MS, Bethony JM, Pickering DA, de Oliveira LM, Jariwala A, Santiago H, et al. An enzymatically inactivated hemoglobinase from Necator americanus induces neutralizing antibodies against multiple hookworm species and protects dogs against heterologous hookworm infection. FASEB J. (2009) 23:3007-19. doi: 10.1096/fj.09-131433

225. Zhan B, Liu S, Perally S, Xue J, Fujiwara R, Brophy P, et al. Biochemical characterization and vaccine potential of a heme-binding glutathione transferase from the adult hookworm Ancylostoma caninum. Infect Immun. (2005) 73:6903-11. doi: 10.1128/IAI.73.10.6903-6911.2005

226. Xiao S, Zhan B, Xue J, Goud GN, Loukas A, Liu Y, et al. The evaluation of recombinant hookworm antigens as vaccines in hamsters (Mesocricetus auratus) challenged with human hookworm, Necator americanus. Exp Parasitol. (2008) 118:32-40. doi: 10.1016/j.exppara.2007.05.010

227. Skwarczynski M, Dougall AM, Khoshnejad M, Chandrudu S, Pearson MS, Loukas A, et al. Peptide-based subunit vaccine against hookworm infection. PLoS ONE. (2012) 7:e0046870. doi: 10.1371/journal.pone.0046870

228. Pearson MS, Pickering DA, Tribolet L, Cooper L, Mulvenna J, Oliveira LM, et al. Neutralizing antibodies to the hookworm hemoglobinase Na-APR1: implications for a multivalent vaccine against hookworm infection and schistosomiasis. J Infect Dis. (2010) 201:1561-9. doi: 10.1086/651953

229. Bartlett S, Eichenberger RM, Nevagi RJ, Ghaffar KA, Marasini N, Dai Y, et al. Lipopeptide-based oral vaccine against hookworm infection. J Infect Dis. (2020) 221:934-42. doi: 10.1093/infdis/jiz528

230. Hang J, He L, Abuzeid A, Huang Y, Liu Y, Yan X, et al. Molecular characterization and tissue localization of glutathione S-transferase from adult Ancylostoma ceylanicum. J Helminthol. (2020) 94:e118. doi: 10.1017/S0022149X20000012

231. Zhan B, Perally S, Brophy PM, Xue J, Goud G, Liu S, et al. Molecular cloning, biochemical characterization, and partial protective immunity of the hemebinding glutathione S-transferases from the human hookworm Necator americanus. Infect Immun. (2010) 78:1552-63. doi: 10.1128/IAI.00848-09

232. Diemert DJ, Lobato L, Styczynski A, Zumer M, Soares A, Gazzinelli MF. A comparison of the quality of informed consent for clinical trials of an experimental hookworm vaccine conducted in developed and developing countries. PLoS Negl Trop Dis. (2017) 11:e0005327. doi: 10.1371/journal.pntd.0005327

233. Zinsou JF, Honpkehedji J, Claude DAJ, Adegbite BR, Edoa JR, Van Leeuwen $\mathrm{R}$, et al. OC 8521 Preliminary report on safety of co-administered human hookworm vaccine candidates Na-APR-1 (M74)/Alhydrogel $($ and Na-GST-

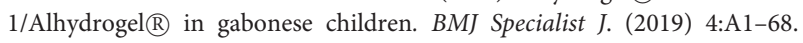
doi: 10.1136/bmjgh-2019-EDC.28

234. Adegnika A, de Vries S, Zinsou FJ, Honkpehedji J, Dejon JC, Loembe MM, et al. SAFETY AND Immunogenicity of co-administered hookworm

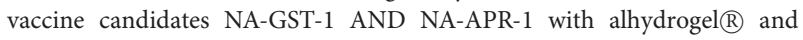
glucopyranosyl-lipid a in gabonese adults: interim resULTS. BMJ Global Health. (2017) 2(Suppl. 2):A12-3. doi: 10.1136/bmjgh-2016-000260.29

235. Noon JB, Schwarz EM, Ostroff GR, Aroian RV. A highly expressed intestinal cysteine protease of Ancylostoma ceylanicum protects vaccinated hamsters from hookworm infection. PLoS Negl Trop Dis. (2019) 13:e0007345. doi: 10.1371/journal.pntd.0007345
236. Loukas A, Bethony JM, Williamson AL, Goud GN, Mendez S, Zhan B, et al. Vaccination of dogs with a recombinant cysteine protease from the intestine of canine hookworms diminishes the fecundity and growth of worms. J Infect Dis. (2004) 189:1952-61. doi: 10.1086/386346

237. Kuśmierek N, Babecka M, Osak O, Popiołek M. Occurrence of geohelminths in the soil of children's playgrounds and green areas in the city of Wrocław, Poland. Ann Parasitol. (2020) 66:231-6. doi: 10.17420/ap6602.259

238. Zdybel J, Karamon J, Kłapeć T, Włodarczyk-Ramus M, Rózycki M, BilskaZajac E, et al. Negative effect of flocculant (cationic acrylamide) on detectability of the nematode eggs in sewage sludge. J Environ Manage. (2019) 231:905-8. doi: 10.1016/j.jenvman.2018.10.105

239. Zdybel J, Karamon J, Rózycki M, Bilska-Zajac E, Kłapeć T, Cencek, T. Characterisation of a new, highly effective method for detecting nematode eggs (Ascaris spp., Toxocara spp., Trichuris spp.) in sewage sludge containing flocculants. Exp Parasitol. (2016) 170:198-206. doi: 10.1016/j.exppara.2016.09.011

240. Bundy DA, de Silva N, Appleby LJ, and Brooker SJ. Intestinal nematodes: ascariasis. In: Ryan ET, Hill DR, Solomon T, Aronson NE, Endy TP, editors. Hunter's Tropical Medicine and Emerging Infectious Diseases (Tenth Edition). Amsterdam: Elsevier (2020). p. 840-4. doi: 10.1016/B978-0-323-55512-8.00112-5

241. World Health Organization. Guideline: Preventive Chemotherapy to Control Soil-Transmitted Helminth Infections in at-Risk Population Groups. Geneva: World Health Organization (2017).

242. Anderson T, Romero-Abal M, Jaenike J. Genetic structure and epidemiology of Ascaris populations: patterns of host affiliation in Guatemala. Parasitology. (1993) 107:319-34. doi: 10.1017/S0031182000079294

243. Liu G-H, Wu C-Y, Song H-Q, Wei S-J, Xu M-J, Lin R-Q, et al. Comparative analyses of the complete mitochondrial genomes of Ascaris lumbricoides and Ascaris suum from humans and pigs. Gene. (2012) 492:110-6. doi: 10.1016/j.gene.2011.10.043

244. Luo H, Zhang H, Li K, Lan Y, Shahzad M, Wang X, et al. Molecular characterization of ascaris from Tibetan pigs by three mitochondrial markers of nad1, cox1 and cox2. Trop Biomed. (2017) 34:576-82.

245. Xu M-J, Fu J-H, Zhou D-H, Elsheikha HM, Hu M, Lin R-Q, et al. Ascaris lumbricoides and Ascaris suum: comparative proteomic studies using 2-DE coupled with mass spectrometry. Int J Mass Spectrometry. (2013) 339:1-6. doi: 10.1016/j.ijms.2013.02.002

246. Urban J Jr, Alizadeh H, Romanowski R. Ascaris suum: development of intestinal immunity to infective second-stage larvae in swine. Exp Parasitol. (1988) 66:66-77. doi: 10.1016/0014-4894(88)90051-3

247. Chen N, Yuan ZG, Xu MJ, Zhou DH, Zhang XX, Zhang YZ, et al. Ascaris suum enolase is a potential vaccine candidate against ascariasis. Vaccine. (2012) 30:3478-82. doi: 10.1016/j.vaccine.2012.02.075

248. Gazzinelli-Guimarães AC, Gazzinelli-Guimarães PH, Nogueira DS, Oliveira FMS, Barbosa FS, Amorim CCO, et al. IgG induced by vaccination with Ascaris suum extracts is protective against infection. Front Immunol. (2018) 9:2535. doi: 10.3389/fimmu.2018.02535

249. Tsuji N, Suzuki K, Kasuga-Aoki H, Isobe T, Arakawa T, Matsumoto Y. Mice intranasally immunized with a recombinant 16-kilodalton antigen from roundworm Ascaris parasites are protected against larval migration of Ascaris suum. Infect Immun. (2003) 71:5314-23. doi: 10.1128/IAI.71.9.5314-5323.2003

250. Versteeg L, Wei J, Liu Z, Keegan B, Fujiwara RT, Jones KM, et al. Protective immunity elicited by the nematode-conserved As37 recombinant protein against Ascaris suum infection. PLoS Negl Trop Dis. (2020) 14:e0008057. doi: 10.1371/journal.pntd.0008057

251. Rudrappa S, Kushwah A, Banerjee A. Identification and characterization of gut antigenic protein of Ascaris suum. J Cell Tissue Res. (2016) 16:5875-79.

252. Hansen EP, Fromm B, Andersen SD, Marcilla A, Andersen KL, Borup A, et al. Exploration of extracellular vesicles from Ascaris suum provides evidence of parasite-host cross talk. J Extracell Vesicles. (2019) 8:1578116. doi: 10.1080/20013078.2019.1578116

253. Barrett J, Brophy P. Ascaris haemoglobin: new tricks for an old protein. Parasitol Today. (2000) 16:90-1. doi: 10.1016/S0169-4758(99)01613-0

254. Goldberg DE. Oxygen-avid hemoglobin of Ascaris. Chem Rev. (1999) 99:3371-8. doi: 10.1021/cr9701521 
255. Vlaminck J, Martinez-Valladares M, Dewilde S, Moens L, Tilleman K, Deforce D, et al. Immunizing pigs with Ascaris suum haemoglobin increases the inflammatory response in the liver but fails to induce a protective immunity. Parasite Immunol. (2011) 33:250-4. doi: 10.1111/j.1365-3024.2010.01274.x

256. Nieuwenhuizen NE, Meter JM, Horsnell WG, Hoving JC, Fick L, Sharp MF, et al. A cross-reactive monoclonal antibody to nematode haemoglobin enhances protective immune responses to Nippostrongylus brasiliensis. PLoS Negl Trop Dis. (2013) 7:e2395. doi: 10.1371/journal.pntd.0002395

257. Ebner F, Morrison E, Bertazzon M, Midha A, Hartmann S, Freund C, et al. CD4+ $\mathrm{T}_{h}$ immunogenicity of the Ascaris spp. secreted products. NPJ vaccines. (2020) 5:25. doi: 10.1038/s41541-020-0171-Z

258. Tsuji N, Suzuki K, Kasuga-Aoki H, Matsumoto Y, Arakawa T, Ishiwata $\mathrm{K}$, et al. Intranasal Immunization with recombinant Ascaris suum14Kilodalton antigen coupled with cholera Toxin B subunit induces protective immunity to A. suum infection in mice. Infect Immun. (2001) 69:7285-92. doi: 10.1128/IAI.69.12.7285-7292.2001

259. Islam M, Miyoshi T, Yokomizo Y, Tsuji N. Molecular cloning and partial characterization of a nematode-specific $24 \mathrm{kDa}$ protein from Ascaris suum. Parasitology. (2005) 130:131-9. doi: 10.1017/S0031182004006250

260. Tsuji N, Kasuga-Aoki H, Isobe T, Arakawa T, Matsumoto Y. Cloning and characterisation of a highly immunoreactive $37 \mathrm{kDa}$ antigen with multiimmunoglobulin domains from the swine roundworm Ascaris suum. Int J Parasitol. (2002) 32:1739-46. doi: 10.1016/S0020-7519(02)00179-0

261. Tsuji N, Miyoshi T, Islam MK, Isobe T, Yoshihara S, Arakawa T, et al. Recombinant Ascaris 16-Kilodalton protein-induced protection against Ascaris suum larval migration after intranasal vaccination in pigs. J Infect Dis. (2004) 190:1812-20. doi: 10.1086/425074

262. Wei J, Versteeg L, Liu Z, Keegan B, Gazzinelli-Guimaraes AC, Fujiwara RT, et al. Yeast-expressed recombinant As16 protects mice against Ascaris suum infection through induction of a Th2-skewed immune response. PLoS Negl Trop Dis. (2017) 11:e0005769. doi: 10.1371/journal.pntd.0005769

263. Matsumoto Y, Suzuki S, Nozoye T, Yamakawa T, Takashima Y, Arakawa T, et al. Oral immunogenicity and protective efficacy in mice of transgenic rice plants producing a vaccine candidate antigen (As16) of Ascaris suum fused with cholera toxin B subunit. Transgenic Res. (2009) 18:185. doi: 10.1007/s11248-008-9205-4

264. Islam MK, Miyoshi T, Tsuji N. Vaccination with recombinant Ascaris suum 24-kilodalton antigen induces a Th1/Th2-mixed type immune response and confers high levels of protection against challenged Ascaris suum lung-stage infection in BALB/c mice. Int J Parasitol. (2005) 35:1023-30. doi: 10.1016/j.ijpara.2005.03.019

265. Frontera E, Carron A, Serrano F, Roepstorff A, Reina D, Navarrete I. Specific systemic IgG1, IgG2 and IgM responses in pigs immunized with infective eggs or selected antigens of Ascaris suum. Parasitology. (2003) 127:291-8. doi: 10.1017/S003118200300355X

266. Serrano F, Reina D, Frontera E, Roepstorff A, Navarrete I. Resistance against migrating Ascaris suum larvae in pigs immunized with infective eggs or adult worm antigens. Parasitology. (2001) 122:699-707. doi: 10.1017/S0031182001007806

267. Kasuga-Aoki H, Tsuji N, Suzuki K, Isobe T, Yoshihara S. Identification of surface proteins and antigens from larval stages of Ascaris suum by two-dimensional electrophoresis. Parasitology. (2000) 121:671-7. doi: 10.1017/S0031182000006892

268. Islam MK, Miyoshi T, Kasuga-Aoki H, Isobe T, Arakawa T, Matsumoto Y, et al. Inorganic pyrophosphatase in the roundworm Ascaris and its role in the development and molting process of the larval stage parasites. Eur J Biochem. (2003) 270:2814-26. doi: 10.1046/j.1432-1033.2003.03658.x

269. Xu M, Chen N, Song H, Lin R, Huang C, Yuan Z, et al. RNAi-mediated silencing of a novel Ascaris suum gene expression in infective larvae. Parasitol Res. (2010) 107:1499-503. doi: 10.1007/s00436-010-2027-3

270. Islam MK, Miyoshi T, Yamada M, Alim MA, Huang X, Motobu M, et al. Effect of piperazine (diethylenediamine) on the moulting, proteome expression and pyrophosphatase activity of Ascaris suum lung-stage larvae. Acta Tropica. (2006) 99:208-17. doi: 10.1016/j.actatropica.2006. 08.007

271. Islam MK, Miyoshi T, Yamada M, Tsuji N. Pyrophosphatase of the roundworm Ascaris suum plays an essential role in the worm's molting and development. Infect Immun. (2005) 73:1995-2004. doi: 10.1128/IAI.73.4.1995-2004.2005

272. Chen N, Xu M-J, Nisbet AJ, Huang C-Q, Lin R-Q, Yuan Z-G, et al. Ascaris suum: RNAi mediated silencing of enolase gene expression in infective larvae. Exp Parasitol. (2011) 127:142-6. doi: 10.1016/j.exppara.2010. 07.019

273. Huang C-Q, Gasser RB, Cantacessi C, Nisbet AJ, Zhong W, Sternberg PW, et al. Genomic-bioinformatic analysis of transcripts enriched in the thirdstage larva of the parasitic nematode Ascaris suum. PLoS Negl Trop Dis. (2008) 2:e0000246. doi: 10.1371/journal.pntd.0000246

274. Andrade MA, Siles-Lucas M, López-Abán J, Carranza C, PérezArellano JL, Muro A. Antigens from Ascaris suum trigger in vitro macrophage NO production. Parasite Immunol. (2005) 27:235-42. doi: 10.1111/j.1365-3024.2005.00774.x

275. He G, Tian W, Wang P, Wang W, Xi J, Yu Q, et al. Construction of expression vector of ALAg and immune protection of its recombinant protein induced in mice. Zhongguo xue xi chong bing fang zhi za zhi. (2012) 24:62-6; 71.

276. Shears R, Bancroft A, Hughes G, Grencis R, Thornton D. Extracellular vesicles induce protective immunity against Trichuris muris. Parasite Immunol. (2018) 40:e12536. doi: 10.1111/pim.12536

277. Gomez-Samblas M, Garcia-Rodriguez JJ, Trelis M, Bernal D, Lopez-Jaramillo FJ, Santoyo-Gonzalez F, et al. Self-adjuvanting C18 lipid vinil sulfone-PP2A vaccine: study of the induced immunomodulation against Trichuris muris infection. Open Biol. (2017) 7:170031. doi: 10.1098/rsob.170031

278. Wakelin D, Selby GR. Functional antigens of Trichuris muris. The stimulation of immunity by vaccination of mice with somatic antigen preparations. Int $J$ Parasitol. (1973) 3:711-5. doi: 10.1016/0020-7519(73)90061-1

279. Jenkins S, Wakelin D. Functional antigens of Trichuris muris released during in vitro maintenance: their immunogenicity and partial purification. Parasitology. (1983) 86:73-82. doi: 10.1017/S0031182000057188

280. Jenkins SN, Wakelin D. The source and nature of some functional antigens of Trichuris muris. Parasitology. (1977) 74:153-61. doi: 10.1017/S0031182000047648

281. Robinson K, Bellaby T, Wakelin D. Efficacy of oral vaccination against the murine intestinal parasite Trichuris muris is dependent upon host genetics. Infect Immun. (1995) 63:1762-6. doi: 10.1128/IAI.63.5.1762-1766.1995

282. Eichenberger RM, Ryan S, Jones L, Buitrago G, Polster R, Montes de Oca M, et al. Hookworm secreted extracellular vesicles interact with host cells and prevent inducible colitis in mice. Front Immunol. (2018) 9:850. doi: 10.3389/fimmu.2018.00850

283. Hansen EP, Kringel H, Williams AR, Nejsum P. Secretion of RNA-containing extracellular vesicles by the porcine Whipworm, Trichuris suis. J Parasitol. (2015) 101:336-40. doi: 10.1645/14-714.1

284. Tritten L, Geary TG. Helminth extracellular vesicles in hostparasite interactions. Curr Opin Microbiol. (2018) 46:73-9. doi: 10.1016/j.mib.2018.08.002

285. Shears RK, Bancroft AJ, Sharpe C, Grencis RK, Thornton DJ. Vaccination against whipworm: identification of potential immunogenic proteins in Trichuris muris excretory/secretory material. Sci Rep. (2018) 8:4508. doi: 10.1038/s41598-018-22783-y

286. Mohamed Fawzi E, Cruz Bustos T, Gómez Samblas M, González-González G, Solano J, González-Sánchez ME, et al. Intranasal immunization of lambs with serine/threonine phosphatase 2A against gastrointestinal nematodes. (2013) 20:1352-9. doi: 10.1128/CVI.00336-13

287. Bedaso K. Review on current status of vaccines against parasitic diseases of animals. J Vet Sci Technol. (2016) 7:3. doi: 10.4172/2157-7579.1000327

Conflict of Interest: The authors declare that the research was conducted in the absence of any commercial or financial relationships that could be construed as a potential conflict of interest.

Copyright (c) 2020 Zawawi and Else. This is an open-access article distributed under the terms of the Creative Commons Attribution License (CC BY). The use, distribution or reproduction in other forums is permitted, provided the original author(s) and the copyright owner(s) are credited and that the original publication in this journal is cited, in accordance with accepted academic practice. No use, distribution or reproduction is permitted which does not comply with these terms. 